\title{
Three New Species and Six Newly Recorded Species of Jumping Spiders (Araneae: Salticidae) in Taiwan
}

\author{
Kuo-Ming Chen1,2, Tai-Yu Lin ${ }^{1,3}$, Yih-Tsong Ueng1* \\ ${ }^{1}$ Department of Environmental Engineering, Kun Shan University, Taiwan \\ ${ }^{2}$ Tainan Municipal Yongkang Junior High School, Taiwan \\ ${ }^{3}$ Tainan Municipal Dujia Elementary School, Taiwan \\ Email: ^ytueng@gmail.com
}

How to cite this paper: Chen, K.-M., Lin, T.-Y. and Ueng, Y.-T. (2021) Three New Species and Six Newly Recorded Species of Jumping Spiders (Araneae: Salticidae) in Taiwan. Natural Resources, 12, 290-320. https://doi.org/10.4236/nr.2021.129021

Received: August 5, 2021

Accepted: September 27, 2021

Published: September 30, 2021

Copyright $\odot 2021$ by author(s) and Scientific Research Publishing Inc. This work is licensed under the Creative Commons Attribution International License (CC BY 4.0).

http://creativecommons.org/licenses/by/4.0/

(c) (i) Open Access

\begin{abstract}
From August 2013 to August 2014 at Aogu Wetland of Chiayi County, Taiwan, a total of 32 adult spiders of Salticidae were identified, comprising 15 species from 13 genera. This paper describes 3 new species and 6 newly recorded species as follows: Microbianor formosana sp. nov., Euophrys taiwanus sp. nov., and Evarcha chiayiensis sp. nov.; Carrhotus tristis, Evarcha bulbosa, Menemerus bivittatus, Plexippus petersi, Rhene rubrigera, and Synagelides zhilcovae. The males distinguish them from other congeners. In addition, the female Sibianor pullus is described for the first time. Species morphologies and detailed structures are depicted in micrographs to compensate for the lack of textual description.
\end{abstract}

\section{Keywords}

Salticidae, Taxonomy, New Species, Newly Recorded Species, Taiwan

\section{Introduction}

The earliest record of the jumping spider family (Araneae: Salticidae) in Taiwan was in an article on the beneficial insects among Taiwan pests, which mentioned the spider Pyroderses formosanus (Matsumura, 1910) [1]. Subsequently, species were recorded by scholars revising the list of spiders in Taiwan, with a total of 10 genera and 18 species recorded [2]-[9].

As of June 2021, Academia Sinica's Taiwan Species List contained 32 genera and 50 species with the scientific name Salticidae [8]. We collect and report on Salticidae spiders to increase the biodiversity of Taiwan spiders. 


\section{Materials and Methods}

All specimens were collected from Aogu Wetland (23 $\left.30^{\prime} 19^{\prime \prime} \mathrm{N}, 120^{\circ} 07^{\prime} 03^{\prime \prime} \mathrm{E}\right)$ in Chiayi County, Taiwan, from August 2013 to August 2014 each monthly [10]. A sweep net (diameter: $38 \mathrm{~cm}$ ) was used to catch spiders [11]. The purpose of that research was to find the clustering and diversity of the spiders.

The environment in Aogu Wetland includes grassland, terrestrial shrubs, waterside shrubs, and casuarina forest [12]. In total, 15,467 spiders were collected, of which 4576 were adult spiders, belonging to 14 families and 141 morphological species. Among them, 251 specimens of Salticidae were examined [10]. All collected specimens were preserved in $40 \%$ alcohol and brought to a Kun Shan University laboratory, where they were washed and preserved in $75 \%$ alcohol for subsequent identification.

First, determine whether 251 specimens of Salticidae were adult spiders based on the characteristics of the spiders [13]. If they were juvenile and immature spiders, they will not be processed and stored at the Kun-Shan University laboratory. If they were adult spiders, they will continue to be examined using the following references: Huang (2004) [7], Chen and Chen (2013) [8], Davies and Zabka (1989) [13], Simon (1903) [14], Ono et al. (2009) [15], Kim et al. (2000) [16], Kim and Kim (2009) [17], Kim and Lee (2014) [18], Żabka (1985) [19], Żabka and Waldock (2012) [20], Prószynski (2008) [21], World Spider Catalog (2021) [22], and Jumping spiders (2021) [23].

Except for one specimen of the Pseudicius sp. was lost during the photographing process, the remaining 31 adult specimens were stored at the National Museum of Natural Science (NMNS), Taichung (NMNS-8370-001-NMNS8370-014). The other 219 were young spiders, the characteristics of the species are no obvious and it is difficult to distinguish.

Color images of specimens were captured using a stereo zoom microscope (SZ-60, OLYMPUS) and a Nikon CoolPix 4500 camera. The images of the male genitalia were captured under a microscope (Eclipse 50i, NIKON). The measurement accuracy of the body length and each part of each specimen was 0.01 $\mathrm{mm}$.

\section{Abbreviations}

Abbreviations used in the paper are as follows: AER, anterior eye row; ALE, anterior lateral eye; AME, anterior median eye; PLE, posterior lateral eye; PME, posterior median eye; MOA, median ocular area (area between promarginal teeth and retromarginal teeth). Eye size was measured as the length of its long axis, but for the PME, it was the length of its horizontal plane.

Leg length is femur + patella + tibia + metatarsus + tarsus lengths; pedipalp length is femur + patella + tibia + cymbium lengths; MOA-L, median ocular area length (from AME to PME); MOA-AW, anterior width of the AME lenses calculated from their external edges; MOA-PW, posterior width of the PME lenses calculated from their external edges; AMI, anterior median eye interval; AMLI, anterior median and lateral eye interval; PMI, posterior median eye interval; 
PMLI, posterior median and lateral eye interval [8].

\section{Results}

From August 2013 to August 2014 at Aogu Wetland, in total 251 specimens Salticidae were identified: 219 specimens were juvenile or immature, and 32 specimens were adult spider (Appendix 1). These adult spiders with 13 genera and 15 species identified, including 3 new species and 6 newly recorded species as follows: Microbianor formosana sp. nov., Euophrys taiwanus sp. nov., and Evarcha chiayiensis sp. nov.; Carrhotus tristis, Evarcha bulbosa, Menemerus bivittatus, Plexippus petersi, Rhene rubrigera, and Synagelides zhilcovae, respectively. These are distinguishable from other congeners of the male spider. Additionally, the female Sibianor pullus is also described herein for the first time. Species morphology and detailed structures are shown in micrographs to compensate for the lack of textual description.

\subsection{Key for the Identification Salticidae Species at Aogu Wetland of Taiwan}

1) Body shape resembles that of an ant (Figure 1, Figure 32 )...............

Body shape unlike that of an ant......................................

2) Promarginal teeth (2 teeth), cervical groove not notable (Figure 32)Synagelides zhilcovae (new record).

Promarginal teeth (more than 2 teeth), cervical groove notable (Figure 1) Myrmarachne formosicola.

3) The ocular area is longer than one-half the length of the cephalothorax.....4

The ocular area is shorter than one-half the length of the cephalothorax.......7

4) The length and width of the cephalothorax are almost equal (Figure 30(B))-Rhene rubrigera (new record).

The length of the cephalothorax is much greater than the width (Figure 22(A)) . .5

5) The posterior middle eye is closer to the anterior eye, but farther away from the posterior eye (Figure 2)-Bianor angulosus.

The posterior middle eye is equidistant from the anterior and posterior eyes (Figure 3(A), Figure 22(A)).

6) Body length less than $2 \mathrm{~mm}$, radial furrow not notable (Figure 25(A)) Microbianor formosana sp. nov.

Body length greater than $2 \mathrm{~mm}$, radial furrow notable (Figure 3(A))-Sibianor pullus.

7) Body length less than $3 \mathrm{~mm}$ (Figure 10)-Euophrys taiwanus sp. nov.

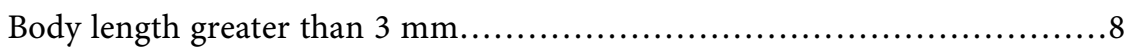

8) Male spider....................................................

Female spider..................................................... 16

9) Pdipalpal tibia longer than the cymbium (Figure 4(B)) - Hasarius adansoni

Pdipalpal tibia shorter than the cymbium..............................10 

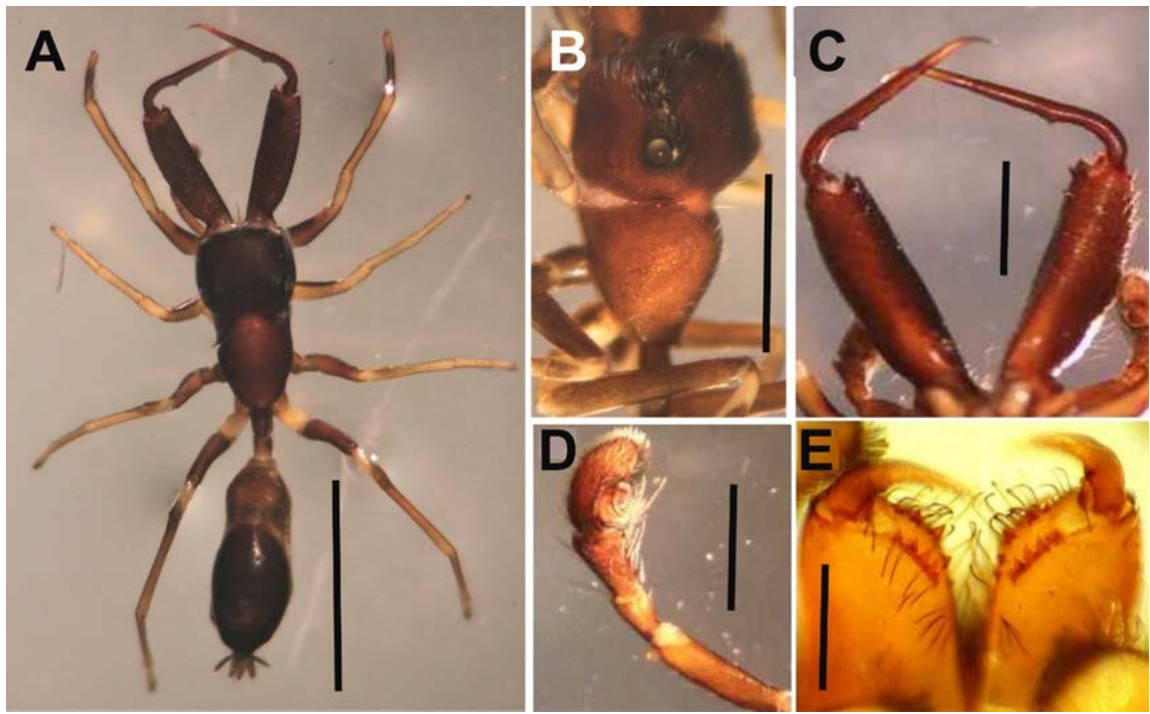

Figure 1. Myrmarachne formosicola (NMNS-8370-010). (A-D) Male; (A) dorsal view; (B) cephalothorax; (C) chelicera and fangs; (D) palpal organ; (E) female promarginal teeth, retromarginal teeth, and fang. Scale bars: $A=3 \mathrm{~mm}, \mathrm{~B}-\mathrm{C}, \mathrm{E}=1 \mathrm{~mm}, \mathrm{D}=0.5 \mathrm{~mm}$.
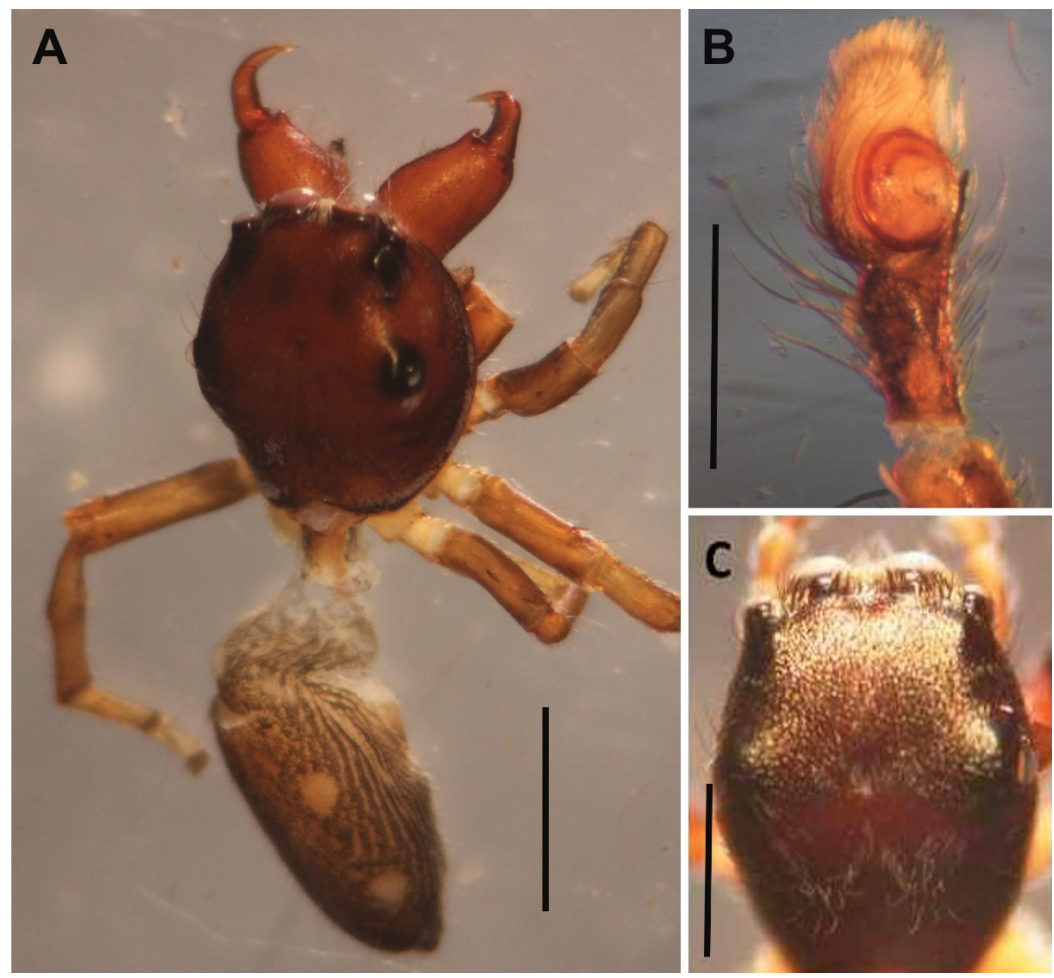

Figure 2. Bianor angulosus (NMNS-8370-005). (A) Male dorsal view; (B) male pedipalp and palpal organ ventral view; $(\mathrm{C})$ female cephalothorax and ocular area dorsal view. Scale bars: $\mathrm{A}=2 \mathrm{~mm}, \mathrm{~B}-\mathrm{C}=1 \mathrm{~mm}$.

10) Bulbus shape is almost round

Bulbus shape is not round; some species have a protuberance

11) Three tibia protuberances (Figure 5)-Cosmophasis lami.

Fewer than 3 tibia protuberances (Figure 16). 

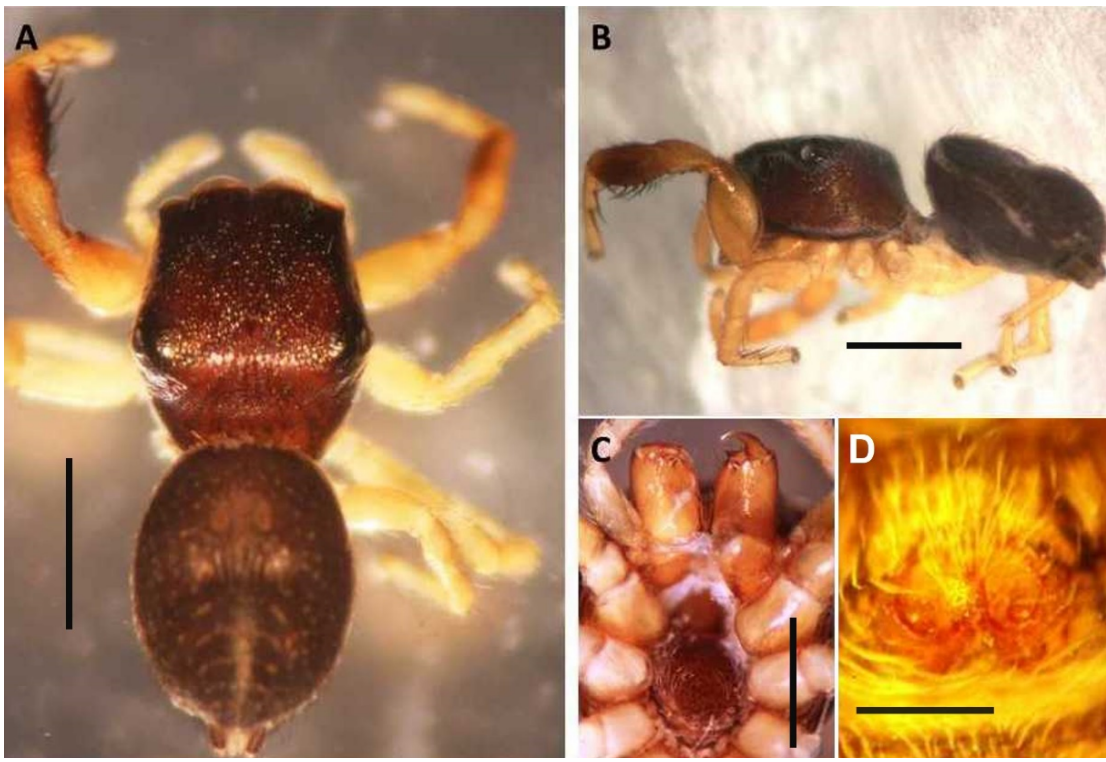

Figure 3. Female Sibianor pullus (NMNS-8370-013). (A) Dorsal view; (B) lateral view; (C) chelicera and sternum; (D) epigynum. Scale bars: $A-C=1 \mathrm{~mm}, \mathrm{D}=0.3 \mathrm{~mm}$.
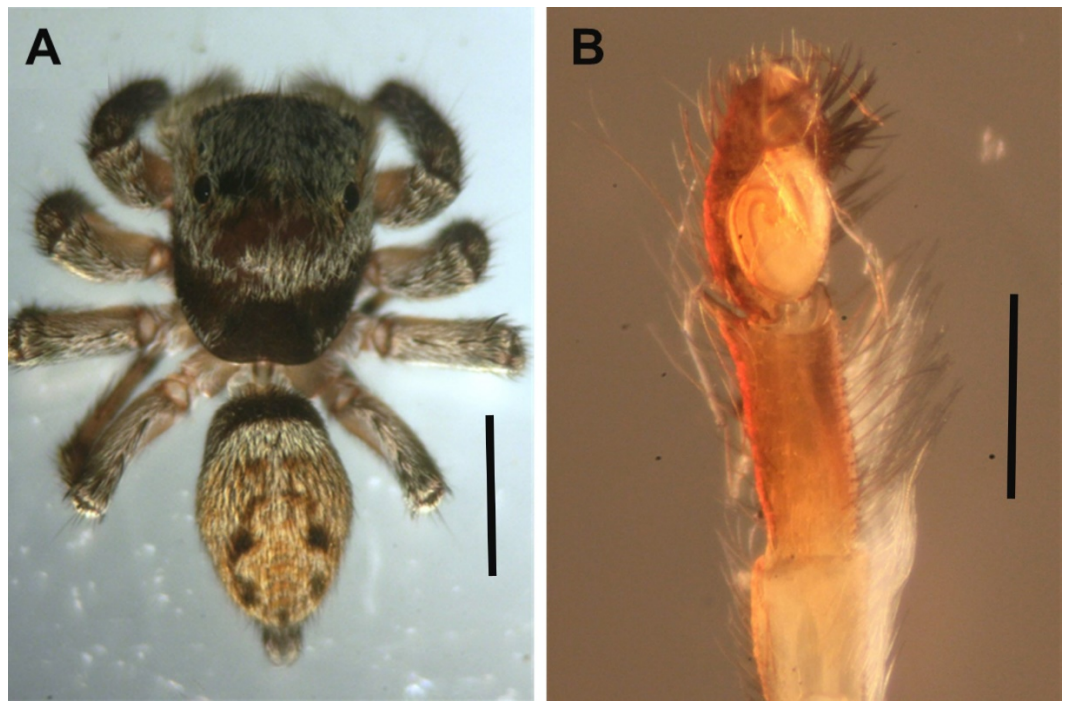

Figure 4. Hasarius adansoni (collected from Tainan City of Taiwan). (A) Female dorsal view; (B) male pedipalpal tibia longer than the cymbium. Scale bars: $A=2 \mathrm{~mm}, \mathrm{~B}=0.3 \mathrm{~mm}$.

12) Tibial protrusion ends with bifurcate apophysis (Figure 15(A)) - Evarcha bulbosa (new record).

Tibia protruding end does not bifurcate (Figure 16(D)) - Evarcha chiayiensis sp. nov.

13) Embolus slender (Figure 8(B), Figure 26(C))

Embolus beak (Figure 6(D), Figure 20(A)) ...........................15

14) The length of the genitalia bulb is greater than the width (Figure 8(B)) Carrhotus tristis (new record).

The length and width of the genitalia bulb are the approximately samePlexippus petersi (new record). 

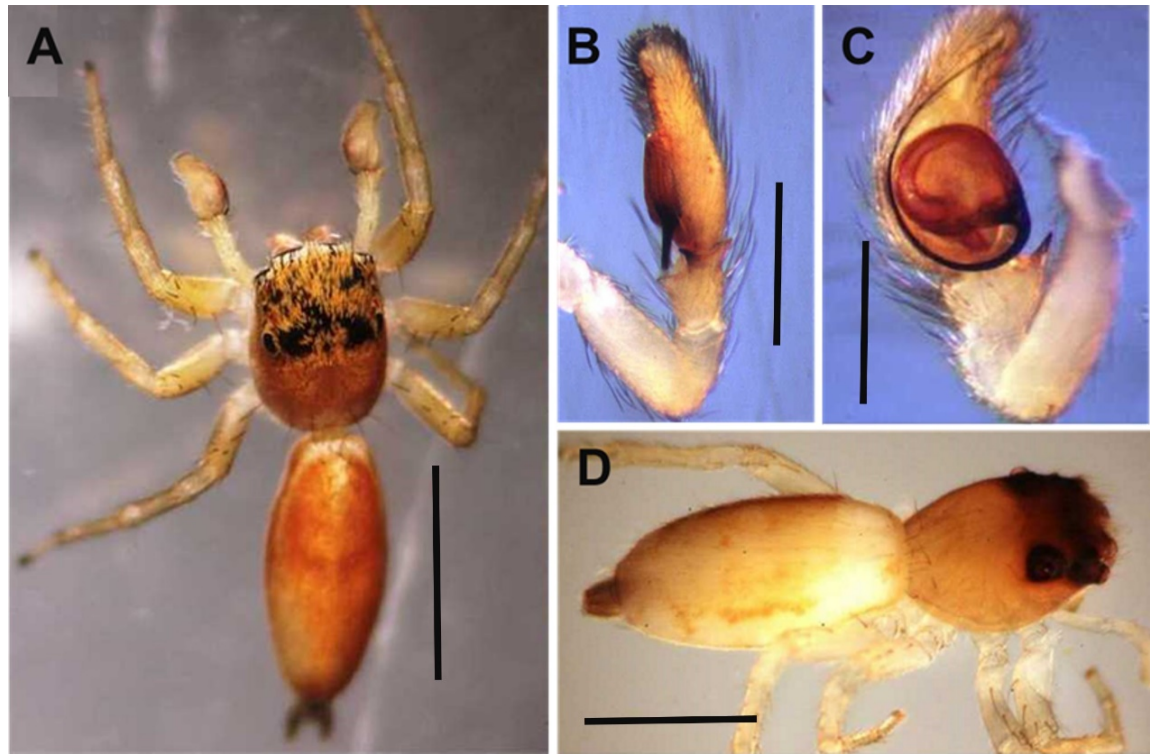

Figure 5. Cosmophasis lami (collected from Tainan City of Taiwan). (A) Male dorsal view; (B) tibia and protuberance; (C) embolus; (D) female lateral view. Scale bars: A, D = $2 \mathrm{~mm}, \mathrm{~B}-\mathrm{C}=0.5 \mathrm{~mm}$.
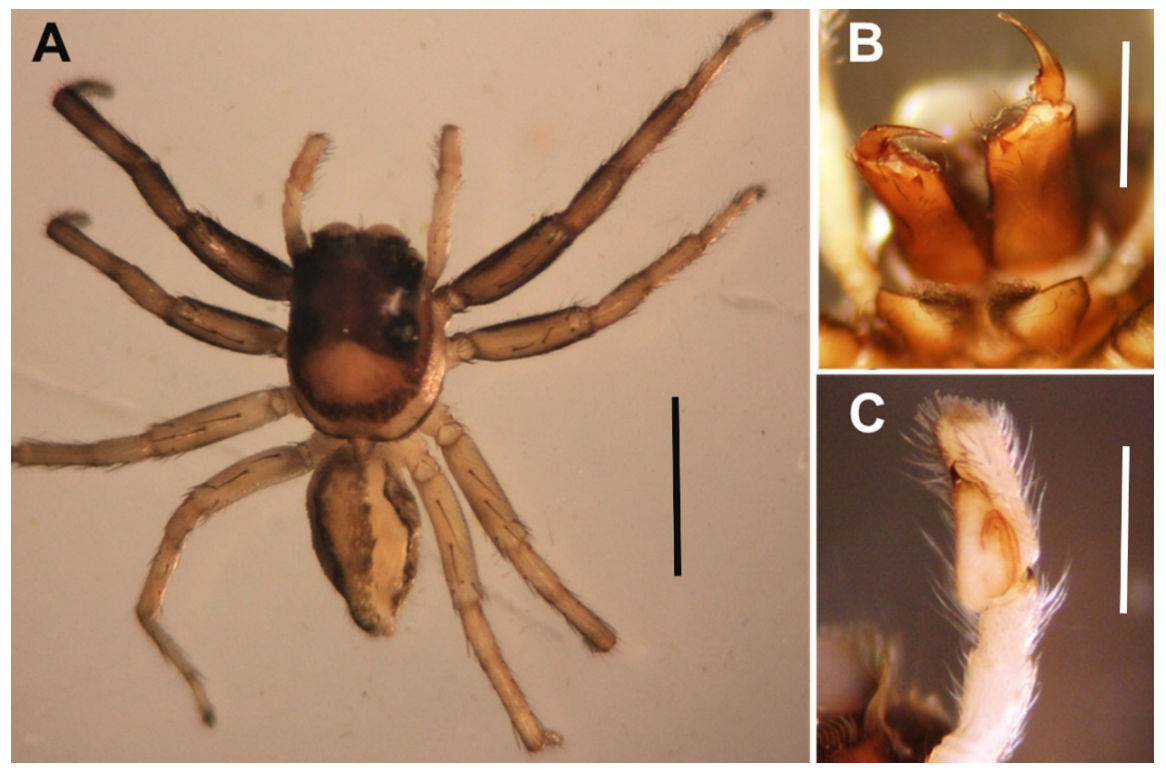

Figure 6. Male Phintella versicolor (NMNS-8370-015). (A) Dorsal view; (B) promarginal teeth, retromarginal teeth and fang; $(C)$ tibia and protuberance. Scale bars: $A=2 \mathrm{~mm}, \mathrm{~B}=$ $0.1 \mathrm{~mm}, \mathrm{C}=0.5 \mathrm{~mm}$.

15) Seminal receptacle channel is clearly visible (Figure 6(C)) - Phintella versicolor.

Seminal receptacle channel is not obvious (Figure 20(A))-Menemerus bivittatus (new record).

16) Under the posterior median eye (PME) and posterior lateral eye (PLE) is a row of microspines (stridulatory spines) (Figure 29)—genus Pseudicius.

No row of microspines under the PME or PLE. . .17 
17) Epigynum dark brown (Figure 7(C)) - Evarcha flavocincta.

Epigynum pink (Figure 4, Figure 5, Figure 21).

18) No light spots behind the ocular area (Figure 5(D)) - Cosmophasis lami.

Light spots behind the ocular area.....................................19

19) The length of the light spot behind the ocular area is greater than its width (Figure 28(A))-Plexippuspetersi (new record).

The width of the light spot behind the ocular area is greater than its length (Figure 4(A), Figure 21(A))

20) The abdomen ventral surface is densely covered with brown spots (Figure 4(A))-Hasarius adansoni.

The abdomen has no stains on the ventral surface (Figure 20)-Menemerus bivittatus (new record).

\subsection{Salticidae Spiders at Aogu Wetland of Taiwan}

\section{Carrhotus tristis Thorell, 1895 (new record) (Figure 8 \& Figure 9)}

Carrhotus tristis Thorell, 1895; Prószyński, 1984; Prószyński, 1992b: 168, f. 8-11.

\section{Type Material}

Male total length (mm) 4.70. Carapace length 2.30, width 1.60; abdomen length 2.10, width 1.50. MOA ratio, MOA-L:MOA-AW:MOA-PW = 0.73:0.97:1.40. AMI:AMLI:PMI:PMLI = 0.10:0.13:1.27:0.23. AME:ALE:PME:PLE = 0.43:016:0.07:0.17. Leg I 3.65 (1.20, 1.25, 0.60, 0.60); leg II 3.65 (1.20, 1.25, 0.60, $0.60)$; leg III $3.60(1.10,1.25,0.50,0.75)$; leg IV $3.65(1.25,1.10,0.60,0.70)$; pedipalp $1.65(0.50,0.25,0.25,0.65)$.
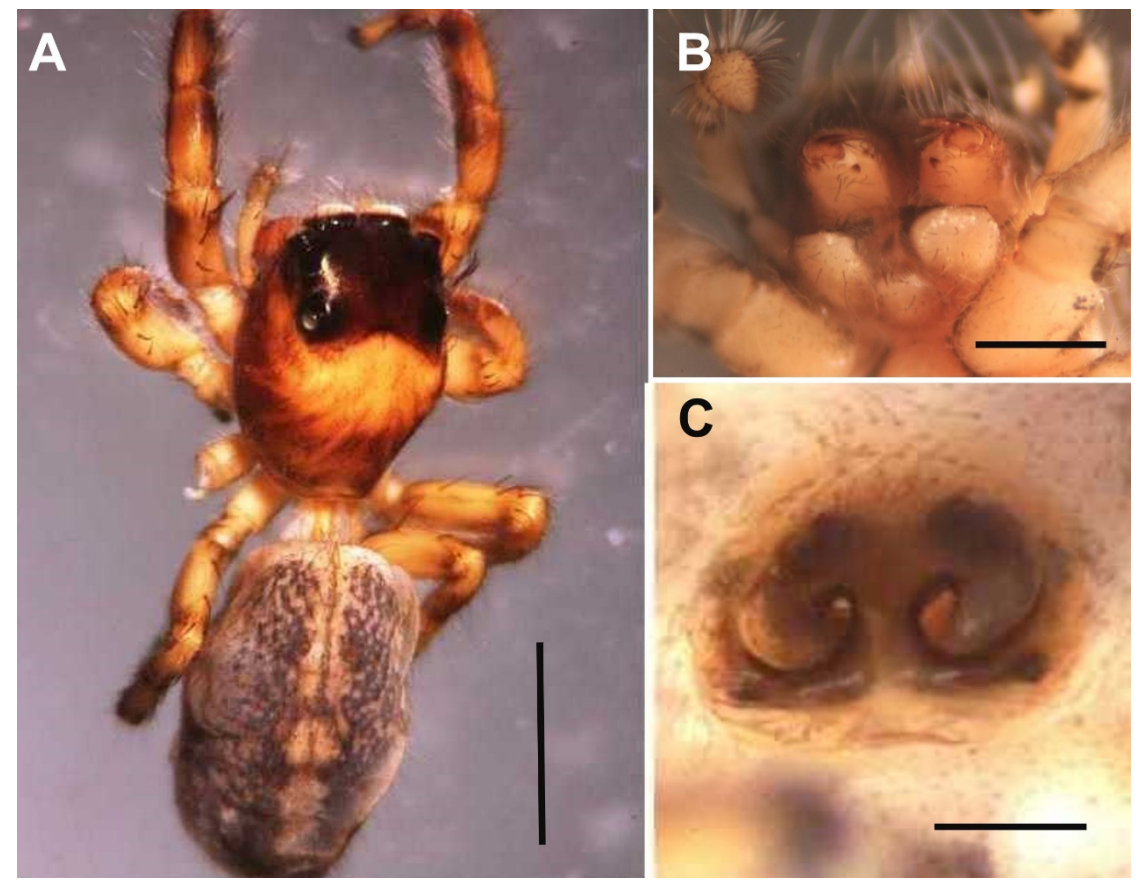

Figure 7. Female Evarcha flavocincta. (A) Dorsal view; (B) chelicera and retromarginal teeth; (C) epigynum. Scale bars: $A=2 \mathrm{~mm}, \mathrm{~B}-\mathrm{C}=0.3 \mathrm{~mm}$. 


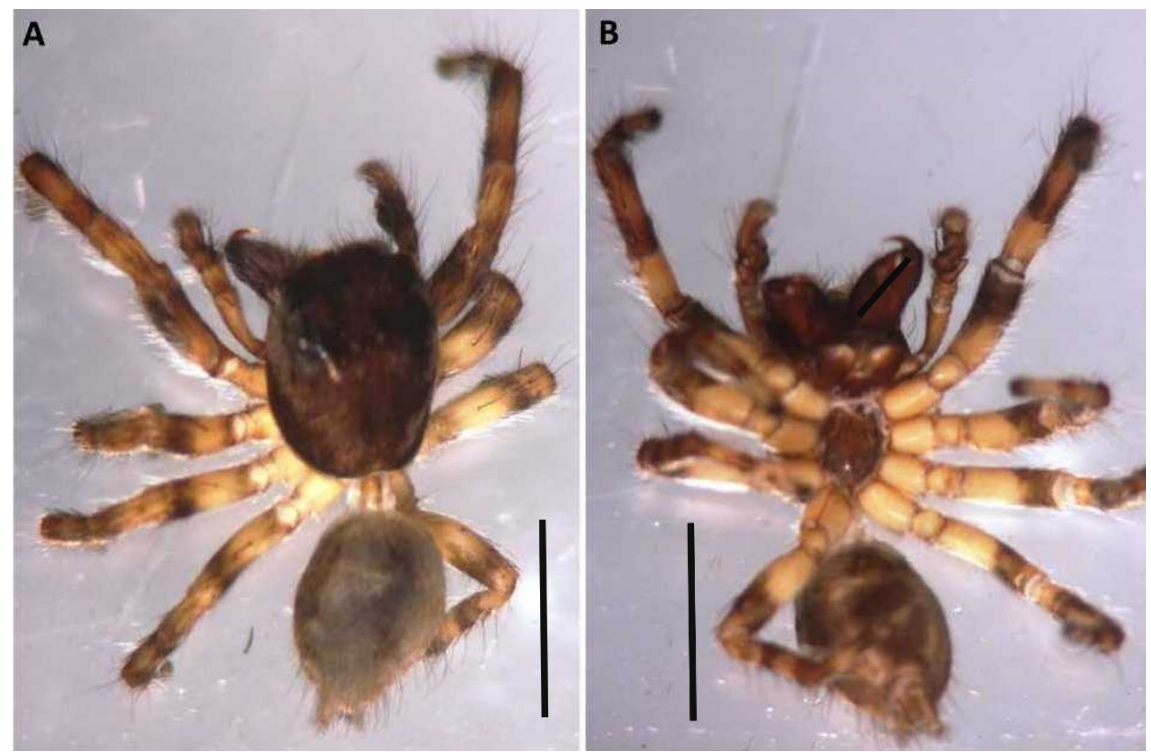

Figure 8. Male Carrhotus tristis. (A) Dorsal view; (B) ventral view. Scale bars: A-B = 2 $\mathrm{mm}$.
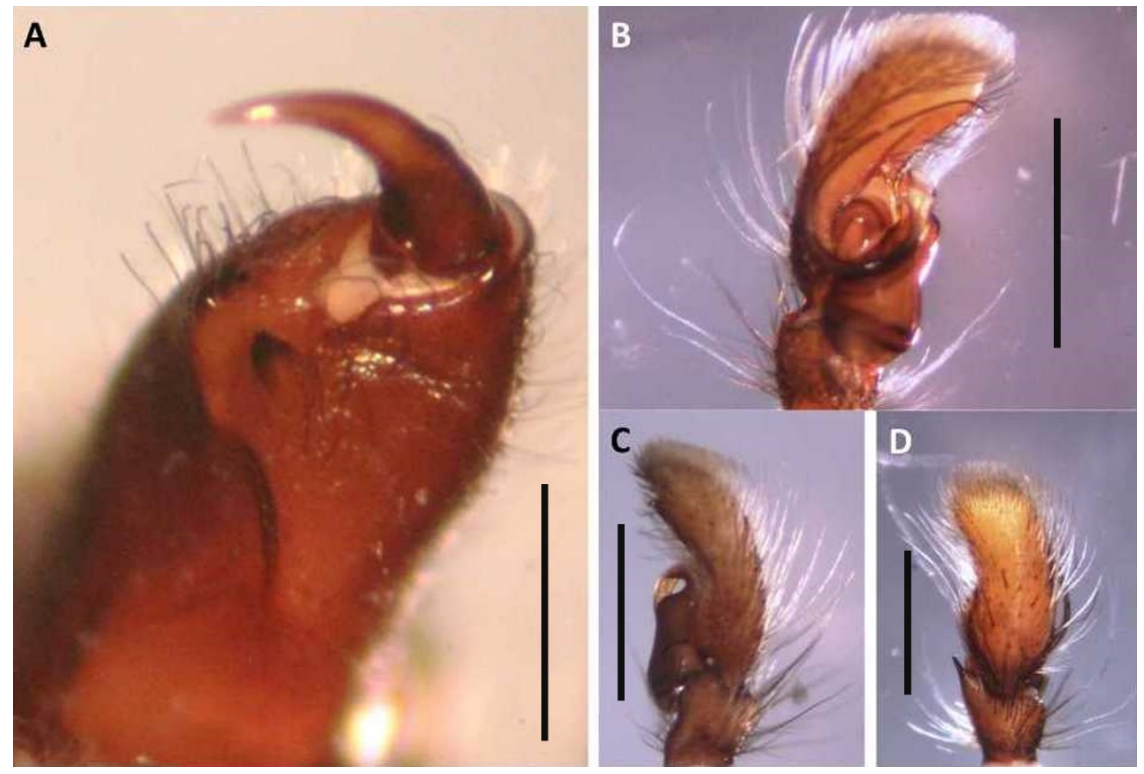

Figure 9. Carrhotus tristis. (A) Chelicerae and marginal teeth; (B-D) pedipalp and palpal organ; (B) front view; (C) lateral view; (D) dorsal view. Scale bars: $A=0.3 \mathrm{~mm}, \mathrm{~B}-\mathrm{D}=0.5$ $\mathrm{mm}$.

\section{Characteristics}

\section{Male}

Cephalothorax brown, ocular area black, thoracic groove obvious. AER recurve. Chelicera and fangs are reddish brown. Two promarginal teeth, 1 retromarginal tooth, labium brown. Sternum brown, oval and front truncated. Abdomen long oval, dorsal yellow brown and with hairs; dorsal view dark brown and with small yellow spots; 3 arcs near the end of abdomen; ventral view dark brown, lateral view light brown. Spinnerets are yellowish brown. The length of 
each leg is approximately the same, with each leg coxa and trochanter yellow, femur front two-thirds yellow and end dark brown, tibia dark brown, metatarsus and tarsus yellow with black rings. Genitalia bulb length is greater than its width, embolus slender, base wraps around the top of the spheroid and extends along the cymbium, tibial apophysis ends with a single sharp process, the cymbium longer than the tibia.

\section{Ecology}

Low grassland of Aogu Wetland, Taiwan.

\section{Distribution}

India, Myanmar, Taiwan area.

Euophrys taiwanus sp. nov. Chen, Lin and Ueng, 2021 (Figures 10-13) Type Material

Holotype: A male specimen collected from Aogu Wetland, Chiayi County, by Tai-Yu Lin (NMNS-8370-001) on February 3, 2014.

Paratypes: Two female specimens collected from the locality on same date as holotype by Tai-Yu Lin (NMNS-8370-002) on February 3, 2014.

\section{Male}

Male total length $(\mathrm{mm})$ 2.45. Carapace length 1.10 , width 0.80 ; abdomen length 1.35, width 0.70 . MOA ratio, MOA-L:MOA-AW:MOA-PW = 0.40:0.530.76. AMI:AMLI:PMI:PMLI $=0.07: 0.04: 0.67: 0.20$. AME:ALE:PME:PLE $=0.22: 011: 0.04: 0.11$. Leg I $1.85(0.60,0.80,0.25,0.20)$; leg II 1.35 (0.45, 0.50, $0.20,0.20)$; leg III $1.65(0.55,0.50,0.25,0.30)$; leg IV $1.80(0.60,0.70,0.25,0.25)$. Pedipalp $1.65(0.33,0.17,0.13,0.33)$.

\section{Female}

Female total length $(\mathrm{mm})$ 2.90; carapace length 1.40 , width 0.90 ; abdomen
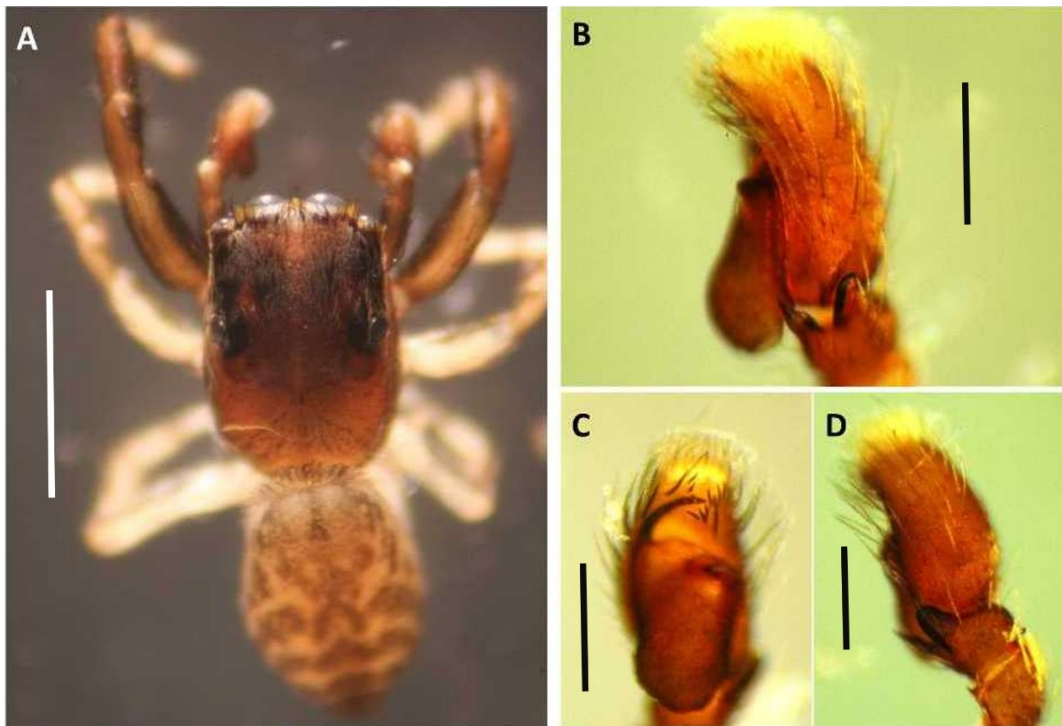

Figure 10. Male Euophrys taiwanus sp. nov. (A) Dorsal view; (B-D) pedipalp and palpal organ; (B) lateral view; (C) dorsal view; (D) ventral view. Scale bars: $A=1 \mathrm{~mm}, \mathrm{~B}-\mathrm{D}=0.5$ $\mathrm{mm}$. 

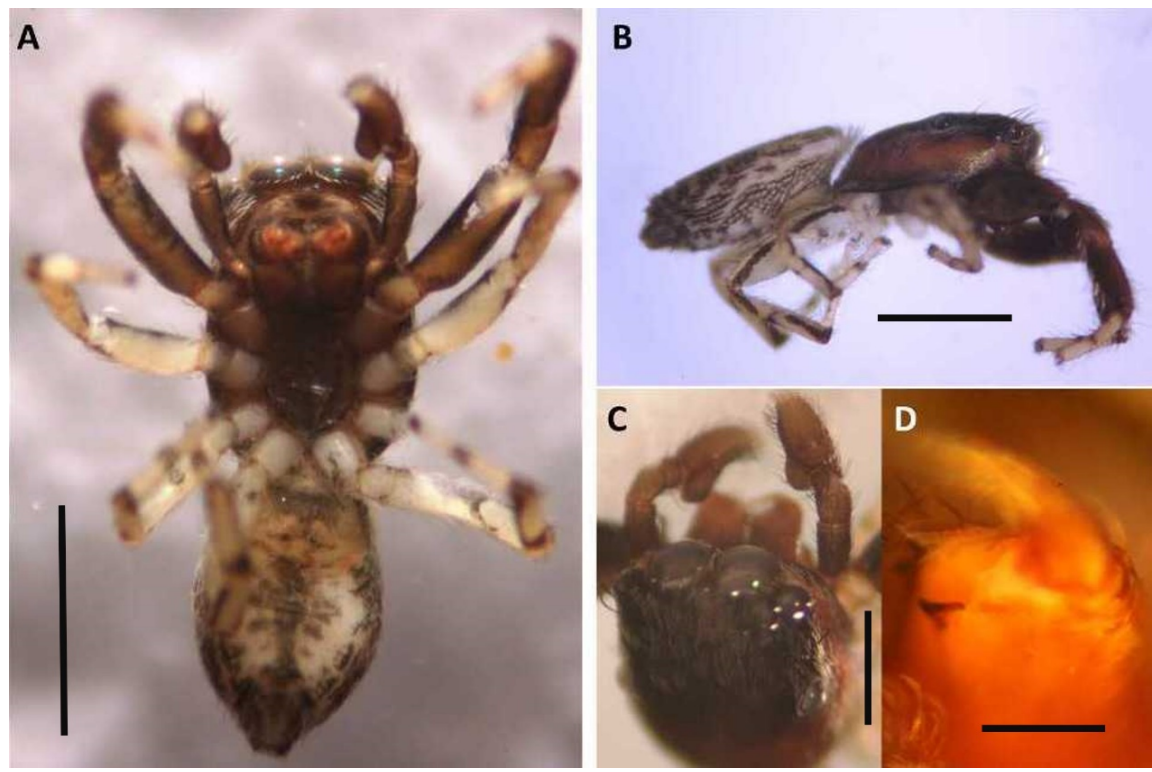

Figure 11. Male Euophrys taiwanus sp. nov. (A) Ventral view; (B) right lateral view; (C) AER; (D) promarginal and retromarginal teeth. Scale bars: A-B $=1 \mathrm{~mm}, \mathrm{C}=0.5 \mathrm{~mm}, \mathrm{D}=$ $0.1 \mathrm{~mm}$.
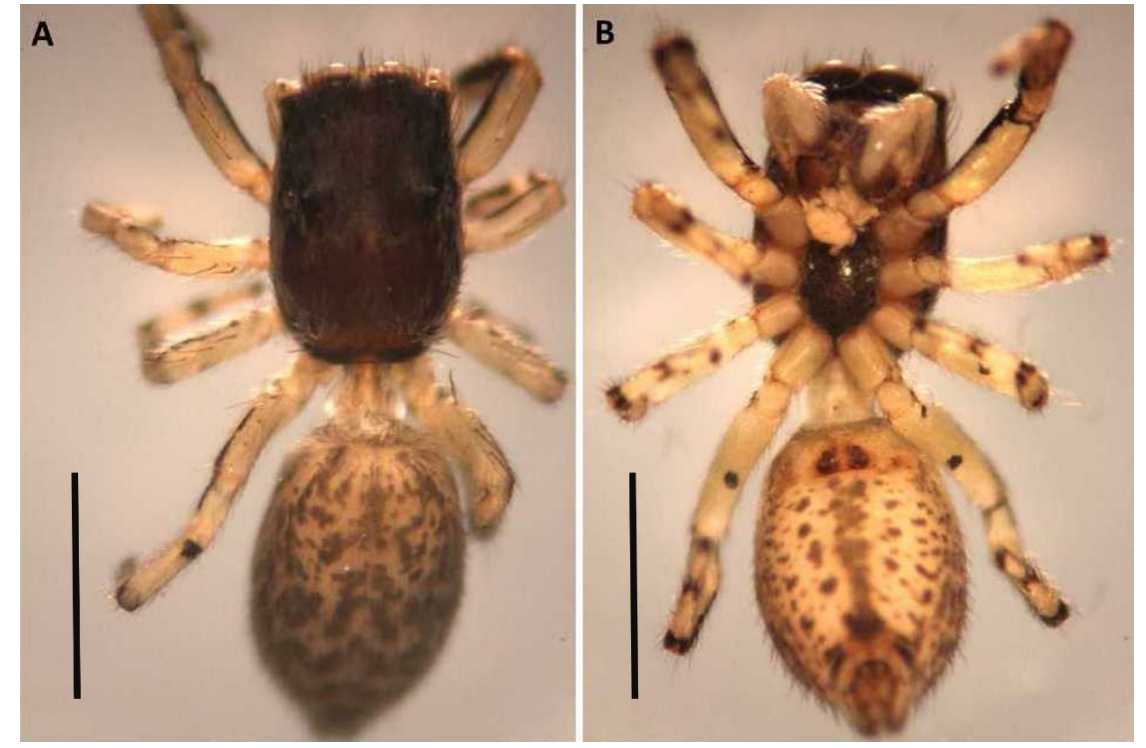

Figure 12. Female Euophrys taiwanus sp. nov. (A) Dorsal view; (B) ventral view. Scale bars: $\mathrm{A}-\mathrm{B}=1 \mathrm{~mm}$.

length 1.50, width 1.00. MOA ratio, MOA-L:MOA-AW:MOA-PW = 0.40:0.53:0.80. AMI:AMLI: PMI:PMLI = 0.04:0.04:0.67:0.12. AME:ALE:PME:PLE $=0.24: 011: 0.06: 0.13$. Leg I $1.95(0.75,0.75,0.20,0.25)$; leg II $1.55(0.50,0.60$, $0.20,0.25)$; leg III $1.65(0.60,0.60,0.20,0.25)$; leg IV $1.75(0.50,0.75,0.25,0.25)$.

\section{Characteristics}

\section{Male}

Cephalothorax brown and flat, ocular area blackish brown, white hairs, fan-shaped radial groove behind the thoracic groove. AER recurve. Chelicera 

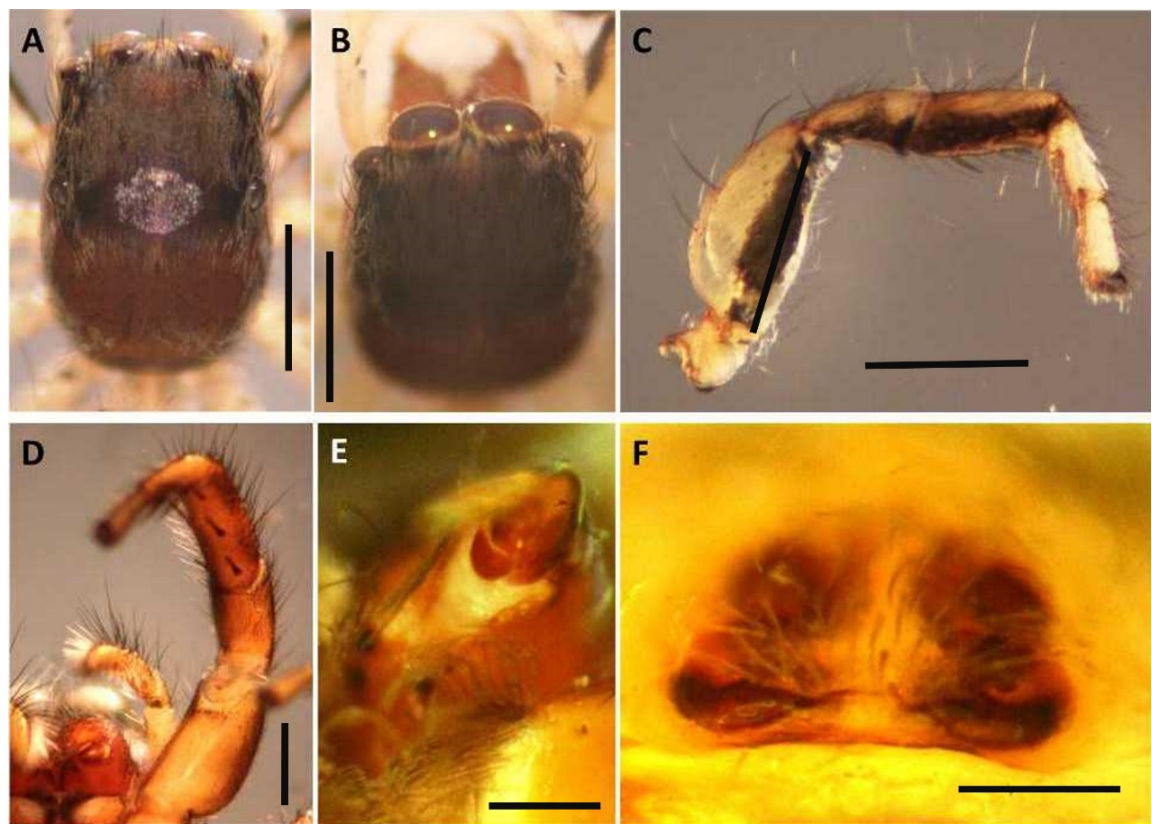

Figure 13. Female Euophrys taiwanus sp. nov. (A) cephalothorax; (B) AER; (C) first leg; (D) first leg ventral view; (E) promarginal and retromarginal teeth; (F) epigynum. Scale bars: $\mathrm{A}-\mathrm{D}=0.5 \mathrm{~mm}, \mathrm{E}-\mathrm{F}=0.1 \mathrm{~mm}$.

and fangs are yellowish brown. Two promarginal teeth, 1 retromarginal tooth, labium brown. Sternum black, shield-shaped, front truncated. Abdomen long ovoid, hairy, dorsal yellow, on the front part of abdomen with large black patches, and 9 - 12 inverted V-shaped black patterns on the second part of abdomen. Abdomen ventral is light yellow. The black longitudinal band extends to the end of the abdomen. Spinnerets are dark brown. Leg lengths are in the order I > IV > III > II. First leg: femur, patella, and tibia brown; metatarsus and tarsus yellow. The second, third, and fourth legs are light yellow, patella and tibia with obvious black belts. Palpal organ brown, tibia shorter than cymbium, tibial apophysis bifurcated. The bifurcation on the side near the spheroid is sharper, and the bifurcation on the other side is blunt. The genitalia bulb protruding, and its length is greater than width. If the genitalia bulb is viewed from the side, the lower end of the bulb is most prominen, and genitalia bulb cover part of the tibia, embolus sickle shaped.

\section{Female}

Cephalothorax brown and flat, ocular area blackish brown, white hairs, fan-shaped radial groove behind the thoracic groove, AER recurve. Chelicere and fangs are yellowish brown. Two promarginal teeth, 1 retromarginal tooth, labium brown. Sternum black, shield-shaped, front truncated. Abdomen long ovoid, hairy, dorsal yellow, on the front part of abdomen with large black patches and black pattern, and 4 - 5 inverted V-shaped black patterns on the second part; 2 pairs of black dots on each side of the black of abdomen vertical band. Abdomen ventral is light yellow. The black longitudinal band extends to the end of the abdomen. Spinnerets are dark brown. Leg lengths are in the order 
I $>$ IV > III > II. Legs light yellow, lateral view of femur, patella, and tibia with obvious black belt; metatarsus and tarsus yellow. The second, third, and fourth legs are light yellow, patella and tibia with obvious black belts, ventral side of the first has 3 pairs of spines. Epigynum is reddish brown, and spermatheca is round and faintly visible.

\section{Ecology}

Aogu Wetland casuarina forest, Euophrys taiwanus sp. nov. is the dominant species of casuarina forest.

\section{Distribution}

Taiwan area.

\section{Evarcha bulbosa Zabka, 1985 (new record) (Figure 14, Figure 15)}

Evarcha bulbosa Zabka, 1985: 222, f. 173-175; Peng, 1989: 159, f. 6A-C; Zhang, Song, and Zhu, 1992: 1, f. 1.1-3; Peng et al., 1993: 64, f. 175-178; Song, Zhu, and Chen, 1999: 510, f. 293J-K, 325L; Yin et al., 2012: 1359, f. 736a-d

\section{Type Material}

Male total length $(\mathrm{mm})$ 5.70. Carapace length 2.80, width 2.10; abdomen length 2.90, width 1.60. MOA ratio, MOA-L:MOA-AW:MOA-PW = 0.90:1.07:1.57. AMI:AMLI:PMI:PMLI $=0.07: 0.10: 1.43: 0.33$. AME:ALE:PME:PLE = 0.50:023:0.06:0.17. Leg I $5.00(1.55,2.05,0.85,0.55)$; leg II 4.25 (1.50, 1.50, 0.75, $0.50)$; leg III 4.39 (1.50, 1.60, 0.74, 0.55); leg IV 4.65 (1.70, 1.50, 0.75, 0.70). Pedipalp $1.95(0.80,0.20,0.20,0.75)$.

\section{Characteristics}

\section{Male}

Cephalothorax black-brown, orange-red bands on both sides and back of ocular area, white hairs on both sides of the band, and black at the end of the cephalothorax, AER recurve. Chelicera and fangs are reddish brown, One promarginal tooth, 1 retromarginal tooth, labium reddish brown. Yellowish brown
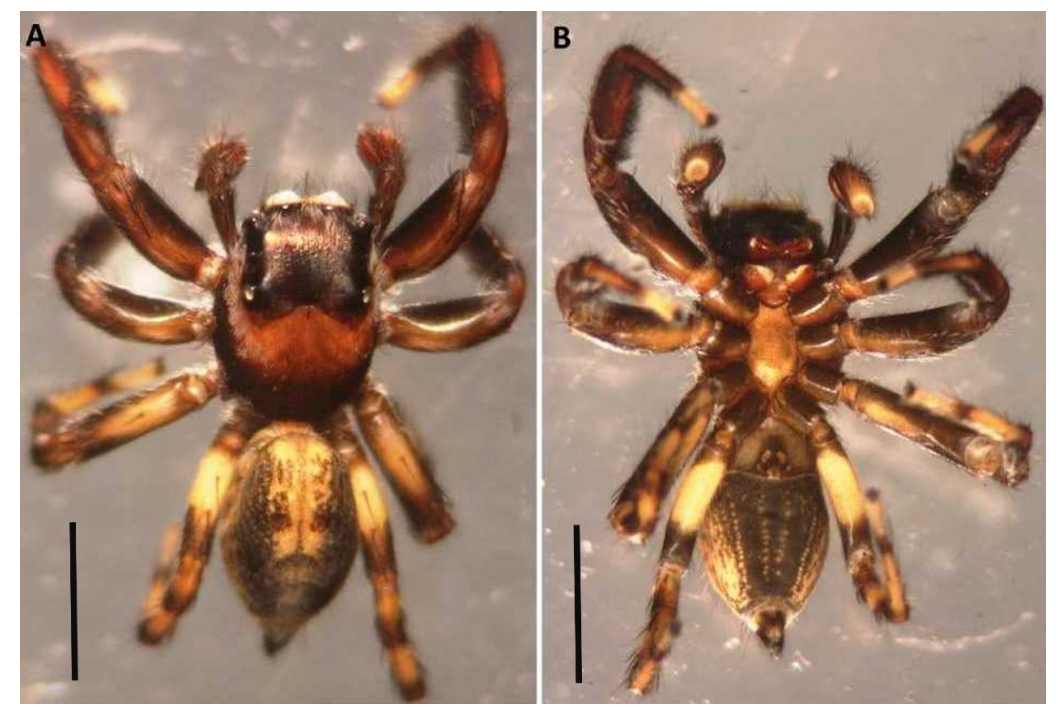

Figure 14. Male Evarcha bulbosa. (A) Dorsal view; (B) ventral view. Scale bars: A-B = 2 $\mathrm{mm}$. 


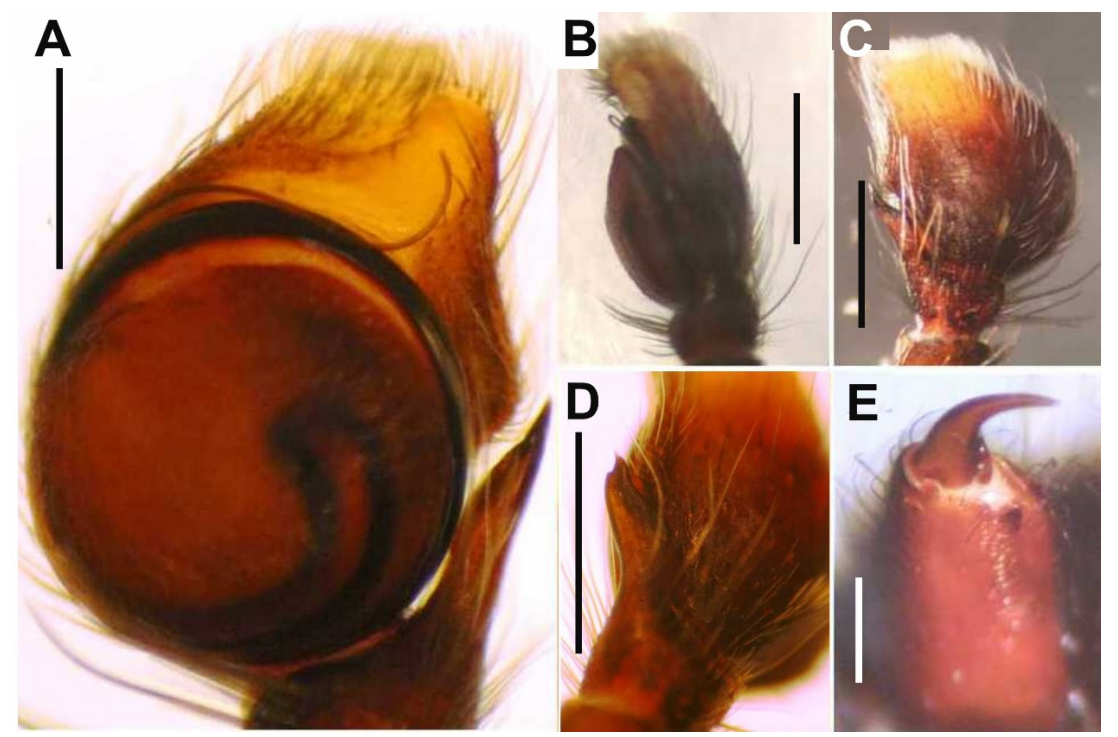

Figure 15. Male Evarcha bulbosa. (A-C) Palpal organ; (A) front view; (B) lateral view; (C) dorsal view; (D) tibial apophysis; $(\mathrm{E})$ chelicerae, promarginal and retromarginal teeth. Scale bars: $\mathrm{A}=0.3 \mathrm{~mm}, \mathrm{~B}-\mathrm{D}=0.5 \mathrm{~mm}, \mathrm{E}=0.1 \mathrm{~mm}$.

with darker central color. Abdomen long ovoid, dorsal view black, 2 yellow belts in the center extend to two-thirds of the abdomen, inside with black patches, and the black parts on both sides are densely covered with small yellow spots; ventral view center black, 4 vertical lines composed of yellow spots, book lung yellowish brown. Spinnerets are dark brown. First leg is the longest and thickest, the first and second legs are dark brown, and the third and fourth legs are yellow and black. Genitalia bulb round, sperm duct visible, embolus elongated, and end flagellated. Tibial apophysis is single and with bifurcations at the end, and the cymbium is longer than the tibia. This species and Evarcha pococki [19] can be distinguished by whether the end of the tibial apophysis is bifurcated.

\section{Ecology}

Low grassland and terrestrial shrubs of Aogu Wetland, Taiwan.

\section{Distribution}

Chinese Mainland, Vietnam, Taiwan area.

Evarcha chiayiensis sp. nov. Chen, Lin and Ueng, 2021 (Figure 16, Figure 17)

Holotype: A male specimen collected from Aogu Wetland, Chiayi County, 4 April 2014 by Tai-Yu Lin (NMNS-8370-003).

\section{Type Material}

Male total length $(\mathrm{mm})$ 3.80. Carapace length 2.00, width 1.60; abdomen length 1.80, width 1.20. MOA ratio, MOA-L:MOA-AW:MOA-PW = 073:0.76:1.35. AMI:AMLI:PMI:PMLI $=0.02: 0.06: 1.20: 0.27$ AME:ALE:PME:PLE $=$ 0.38:0.17:007:0.17. Leg I $2.96(1.00,1.05,0.45,0.46)$; leg II $2.17(0.82,0.75,0.35$, $0.25)$; leg III $3.30(1.00,1.20,0.60,0.50)$; leg IV $3.20(1.05,1.05,0.60,0.50)$. Pedipalp $1.65(0.80,0.20,0.20,0.75)$. 

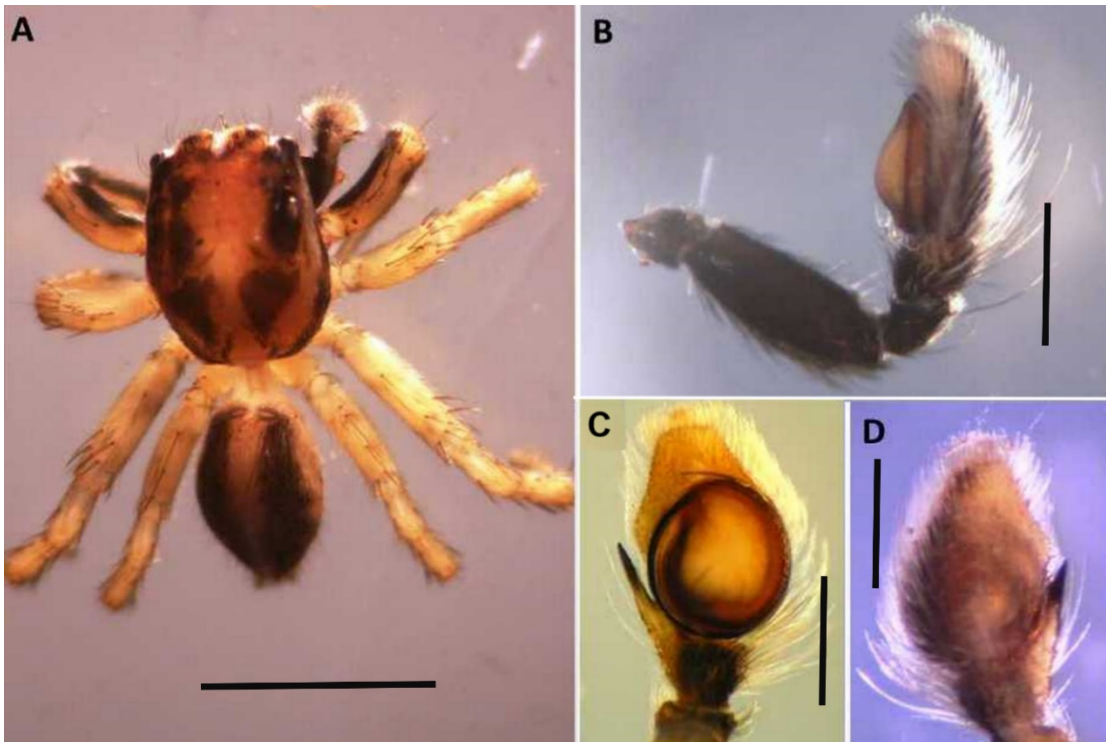

Figure 16. Male Evarcha chiayiensis sp. nov. (A) Dorsal view; (B) pedipalp; (C-D) long apophysis; (C) dorsal view; (D) ventral view. Scale bars: $A=2 \mathrm{~mm}, \mathrm{~B}-\mathrm{D}=0.5 \mathrm{~mm}$.
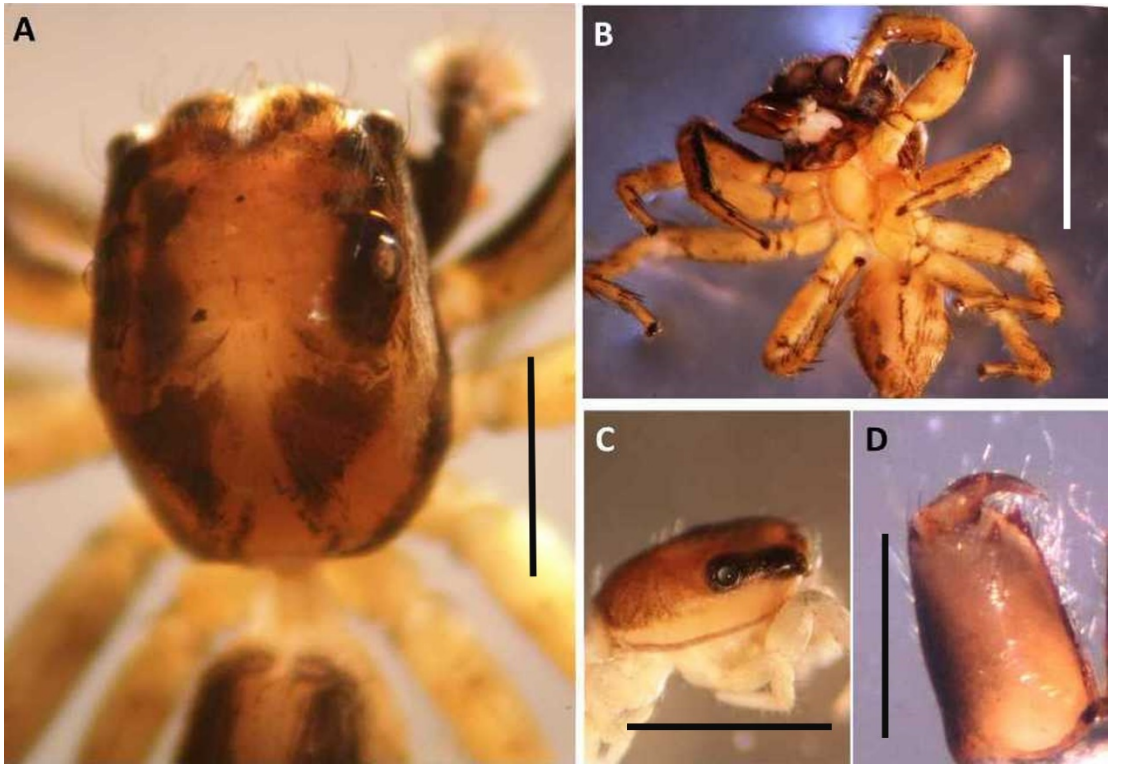

Figure 17. Evarcha chiayiensis sp. nov. (A) Cephalothorax dorsal view; (B) ventral view; (C) lateral cephalothorax; (D) chelicerae, promarginal and retromarginal teeth. Scale bars: $\mathrm{A}-\mathrm{C}=2 \mathrm{~mm}, \mathrm{D}=0.1 \mathrm{~mm}$.

\section{Characteristics}

\section{Male}

Cephalothorax yellowish brown, flat, black around the PME and PLE, forming a black area. A black area is present behind the PLE. The 2 black areas form 2 black vertical bands from a distance, but they are slightly cut off behind the PLE. On observation, the cephalothoraxlis light yellow near the ventral surface. AER recurve. Chelicera and fangs are yellowish brown. Two promarginal teeth, 1 retromarginal tooth. Labium yellowish brown. Sternum yellow, and ovoid. Abdo- 
men long oval, dorsal view orange with a wide black longitudinal band on each side near the edge, and the longitudinal width is approximately one-third of the abdomen's width. Abdomen's ventral surface yellow, with 1 black thin longitudinal line in the center, and on both sides 1 lighter black thin line. Spinnerets are yellowish brown. First leg yellowish brown, and from leg coxa to tarsus with black lines. Second, third, and fourth legs yellow, and trochanter, femur, and patella have black rings on the ventral contact. Palpal organ reddish brown, tibial apophysis monoprocessed, and its end straight and short. Genitalia bulb nearly round, sperm duct faintly visible, embolus elongated and linear and protrude along the genitalia bulb. Cymbium covered with many white hairs and longer than the tibia. This species can be distinguished from Evarcha bulbosa by no bifurcation at the end of the tibial apophysis. Additionally, this species and Evarcha pococki can be distinguished by the palpal organ, detailed description is shown in Table 1 and Figure 16 [18].

\section{Ecology}

Waterside shrubs of Aogu Wetland, Taiwan.

\section{Distribution}

Taiwan area.

Menemerus bivittatus (Dufour, 1831) (new record) (Figures 18-21)

Salticus bivittatus Dufour, 1831: 369, pl. 11, f. 5.

Attus cinctus Walckenaer, 1837: 430.

Marpissa balteata C. L. Koch, 1846: 68, f. 1133.

Salticus convergens Doleschall, 1859: 15, pl. 9, f. 4.

Dendryphantes balteata Simon, 1864: 314.

Menemerus vittatus Simon, 1877b: 59.

Icius convergens Thorell, 1878b: 232.

Menemerus bivittatus Peckham and Peckham, 1886: 292; Petrunkevitch, 1925a: 241, f. 152-153; Davies and Zabka, 1989: 250, pl. 55.

\section{Type Material}

Male total length $(\mathrm{mm})$ 5.20. Carapace length 3.10, width 2.00; abdomen length 2.10, width 1.85. MOA ratio, MOA-L:MOA-AW:MOA-PW= 0.91:1.02:1.62.

Table 1. Comparison of the palpal organ of male Evarcha chiayiensis sp. nov. and E. pococki.

\begin{tabular}{cccc} 
Species & Embolus & Genitalia bulb & Tibial apophysis \\
Evarcha & $\begin{array}{c}\text { thin line shape; } \\
\text { cut out along } \\
\text { the genitalia bulb }\end{array}$ & $\begin{array}{c}\text { nearly round shape, sperm } \\
\text { duct is visible and long, } \\
\text { narrow at the top and wide } \\
\text { at the bottom }\end{array}$ & $\begin{array}{c}\text { end straight, long, and } \\
\text { knife-shaped; more than half } \\
\text { the length of the genitalia bulb; } \\
\text { bifurcation near the inner } \\
\text { side of the cymbium }\end{array}$ \\
E. pococki & $\begin{array}{c}\text { thin line shape, } \\
\text { after touching the } \\
\text { genitalia bulb, it rises } \\
\text { nearly vertically }\end{array}$ & $\begin{array}{c}\text { nearly round shape, visible } \\
\text { and short, wide at the top } \\
\text { and narrow at the bottom }\end{array}$ & $\begin{array}{c}\text { slight curvature at the end, about } \\
\text { half the length of the genitalia } \\
\text { bulb, no bifurcation near the } \\
\text { inner side of the cymbium }\end{array}$ \\
\hline
\end{tabular}




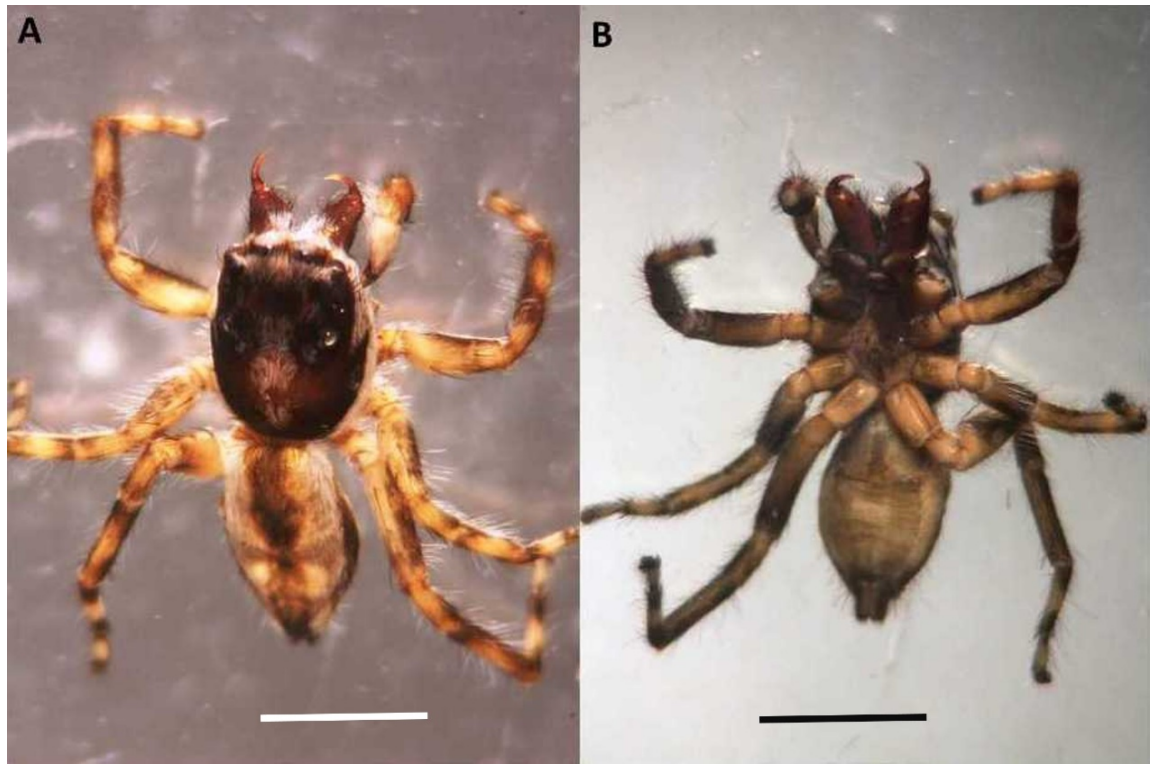

Figure 18. Male Menemerus bivittatus. (A) Dorsal view; (B) ventral view. Scale bars: A-B $=2 \mathrm{~mm}$.

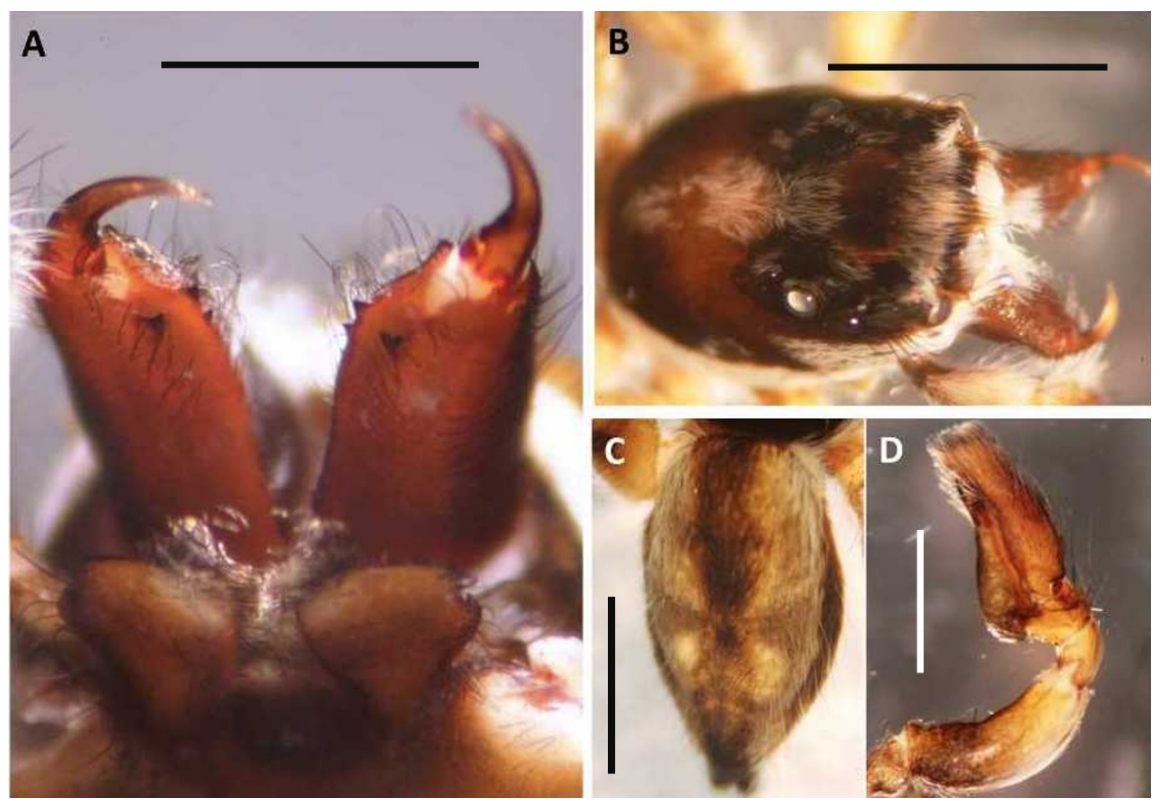

Figure 19. Male Menemerus bivittatus. (A) Chelicera, retromarginal teeth; (B) cephalothorax; (C) abdomen dorsal view; (D) pedipalp. Scale bars: A-C $=1 \mathrm{~mm}, \mathrm{D}=0.5 \mathrm{~mm}$.

AMI:AMLI: PMI:PMLI $=0.13: 0.06: 1.44: 0.33$ AME:ALE:PME:PLE $=$ 0.44:024:0.09:0.22. Leg Iblack; leg II $3.75(1.25,1.65,0.50,0.35)$; leg III 3.55 (1.15, 1.60, 0.50, 0.30); leg IV 4.35 (1.50, 1.75, 0.60, 0.50). Pedipalp 2.10 (0.95, 0.30, $0.25,0.60)$.

Female total length $(\mathrm{mm})$ 6.60. Carapace-length 2.30, width 1.90; abdomenlength 4.30, width 2.30. MOA ratio, MOA-L:MOA-AW:MOA-PW = 0.97:1.10:1.43. AMI:AMLI: PMI:PMLI $=0.10: 0.13: 1.30: 0.23$. AME:ALE:PME:PLE $=0.50: 027: 0.07: 0.20$. Leg I $3.75(1.25,1.50,0.50,0.50)$; leg II 3.70 

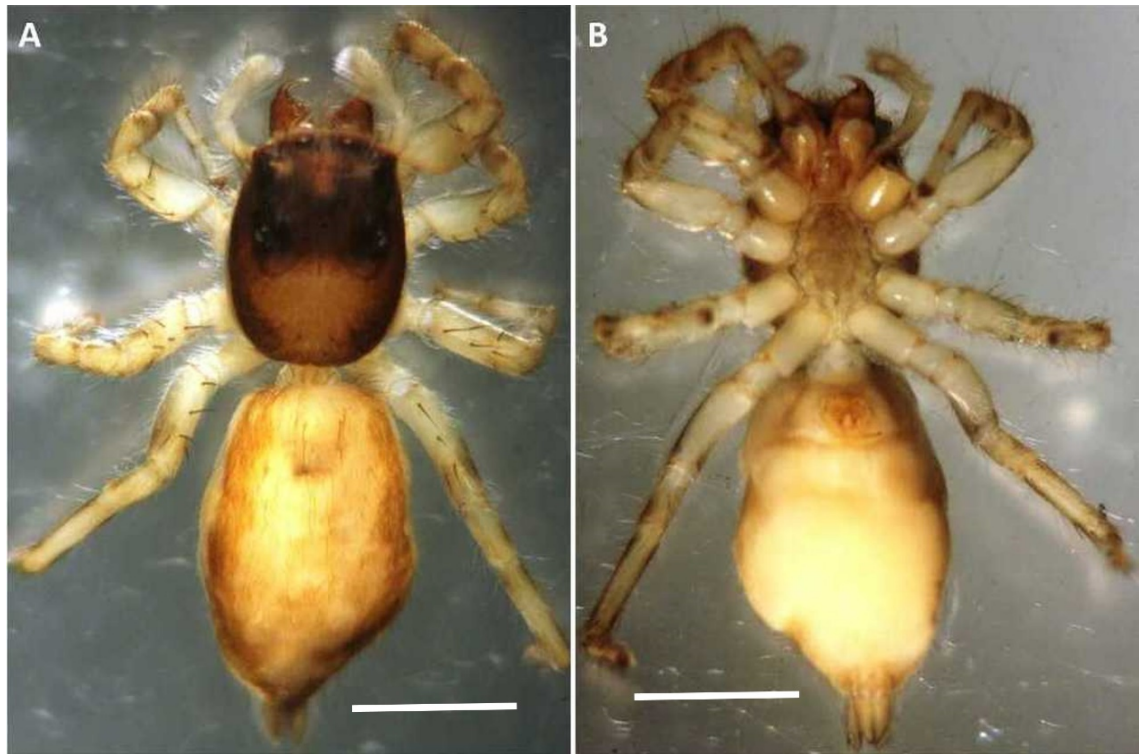

Figure 20. Female Menemerus bivittatus. (A) Dorsal view, (B) ventral view. Scale bars: $\mathrm{A}-\mathrm{B}=2 \mathrm{~mm}$.
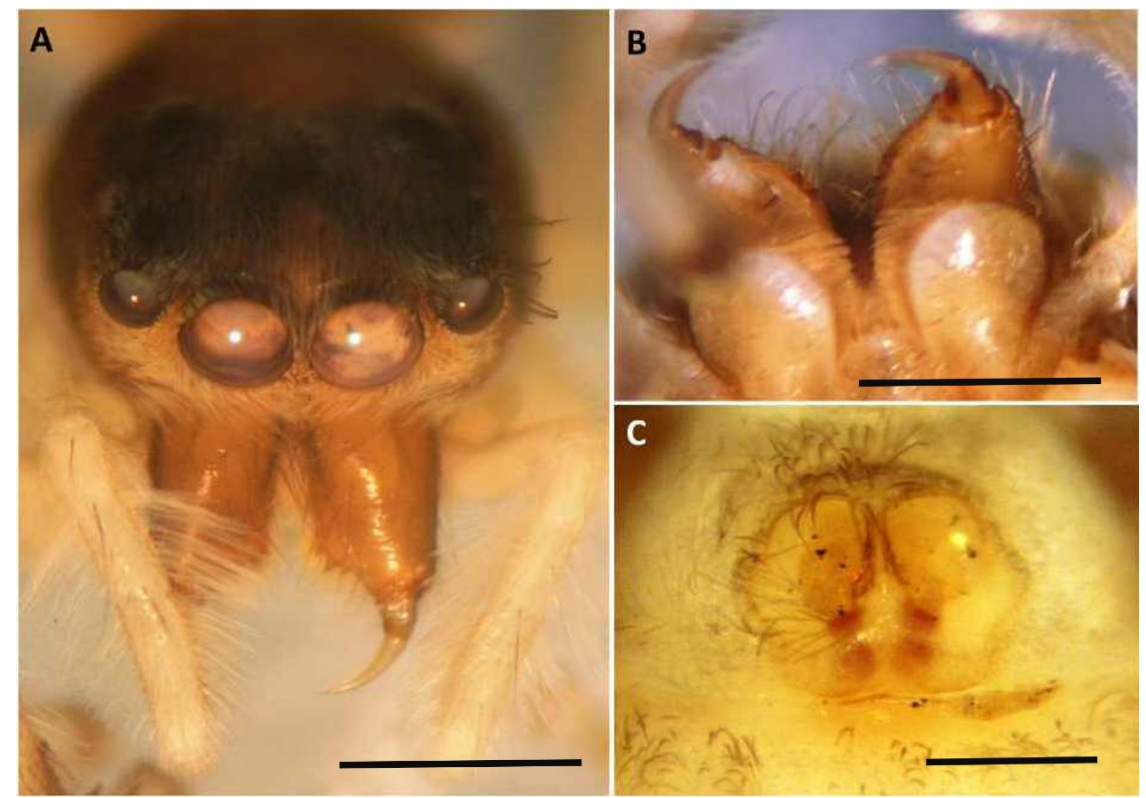

Figure 21. Female Menemerus bivittatus. (A) AER; (B) chelicera; (C) epigynum. Scale bars: $\mathrm{A}-\mathrm{B}=1 \mathrm{~mm}, \mathrm{C}=0.2 \mathrm{~mm}$.

$(1.25,1.50,0.50,0.45)$; leg III $3.70(1.15,1.55,0.50,0.50)$; leg IV $4.45(1.45,2.00$, $0.50,0.50)$.

\section{Characteristics}

\section{Male}

Cephalothorax brown, ocular area dark brown; thoracic groove and behind AER with white hairs AER recurve. Chelicera and fangs reddish brown. Two promarginal teeth, 1 retromarginal tooth. Labium brown. Sternum dark brown, oval, with white hairs on the bottom edge. Abdomen oval, with gray hairs. Wide 
dark brown vertical strip in the center of the back, with or-ange-yellow edges on both sides of the vertical strip, and 2 blackish gray tri-angular stains extending to the sides at three-fifths of the vertical line. The dark-brown vertical strips behind the stain are covered by 2 yellow herringbone stripes and the herringbone stripes are divided abdomen into 3 blocks. Abdomen's ventral surface grayish yellow. Several yellow stripes behind at the extragastric sulcus, and the book lung is yellowish brown. Spinnerets are dark brown. Legs with white hairs, ventral yellowish brown; femur, patella, tibia, metatarsus, and tarsus with black markings. Pedipalp, femur, and tibia are with white hairs tufts on the outside. Genitalia bulb front view is with a vertical line. Protuberance under the genitalia bulb covering approximately half the tibia, embolus base large, base with a hook-shaped protrusion at the end. Cymbium with black hairs with a small protrusion from the base of the dorsal side.

Female

Cephalothorax brown, between the PME and PLE with a butterfly-shaped dark brown block. Cephalothorax has dark-brown stripes on both sides of the edge, a thoracic groove of the middle fossa is in the shape of the number "l", and a horizontal band of white hairs is present on the forehead. AER recurve. Chelicera and fangs are brown. Two promarginal teeth, 1 retromarginal tooth. Labium is brown, and length is greater than width. Sternum grayish black, densely covered with small yellow spots, ovoid, front truncated, and white hairs on the edges. Abdomen oval, covered with scattered black hairs, dorsal view yellow with a brown longitudinal band on each side edge that extends to the end of the abdomen and finally meets; ventral view yellow, without a pattern, and some black hairs are present on the extragastric groove. Spinnerets are yellow. Leg yellow, femur covered with 4 - 5 black hairs on the dorsal side of the leg. Pedipalp densely covered with white hairs; genitalia obvious, pink.

\section{Ecology}

Waterside shrubs and casuarina forest of Aogu Wetland, Taiwan.

\section{Distribution}

Chinese Mainland, Vietnam, Taiwan area.

Microbianor formosana sp. nov. Chen, Lin and Ueng, 2021 (Figures 22-24)

Holotype: A male specimen collected from Aogu Wetland, Chiayi County, on August 2, 2014, by Tai-Yu Lin (NMNS-8370-004).

\section{Type Material}

Male total length $(\mathrm{mm})$ 1.56. Carapace length 0.67 , width 0.70; abdomen length 0.89 , width 0.67 . MOA ratio, MOA-L:MOA-AW:MOA-PW = 058:0.58:0.74. AMI:AMLI: PMI:PMLI $=0.01: 0.01: 0.63: 0.25$. AME:ALE:PME:PLE $=0.16: 0.08: 0.04: 0.11$. Leg I $1.52(0.53,0.60,0.20,0.19)$; leg II $1.21(0.41,0.41$, $0.20,0.19)$; leg III $1.33(0.41,0.53,0.20,0.19)$; leg IV $1.46(0.45,0.57,0.23,0.21)$. Pedipalp $1.08(0.40,0.20,0.07,0.41)$. 

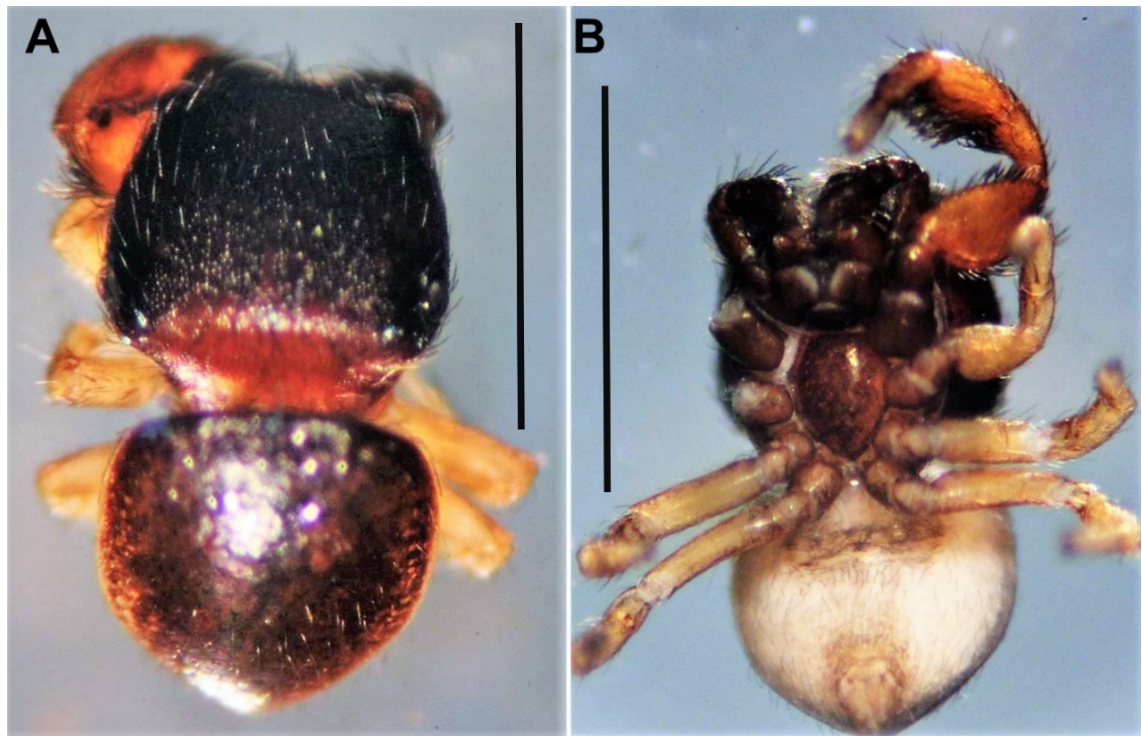

Figure 22. Male Microbianor formosana sp. nov. (A) Dorsal view; (B) ventral view. Scale bars: $\mathrm{A}-\mathrm{B}=1 \mathrm{~mm}$.
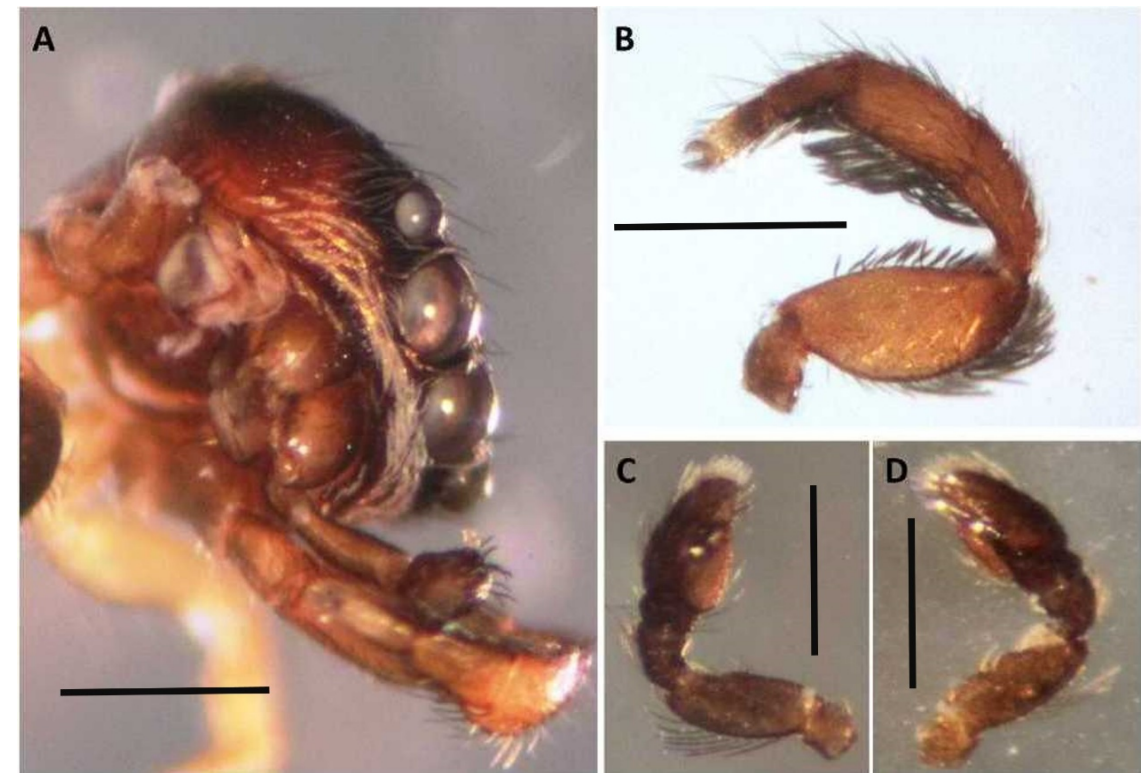

Figure 23. Microbianor formosana sp. nov. (A) AER and chelicerae; (B) first leg; (C-D) lateral palpal organ. Scale bars: A-D $=0.5 \mathrm{~mm}$.

\section{Characteristics}

\section{Male}

Body size small, less than $2 \mathrm{~mm}$, resembles a beetle with a metallic luster. Cephalothorax is dark brown, and ocular area is darker than the chest. Ocular area is widest at the PLE, radial furrow obvious, and ventral surface yellow. AER recurve, and a row of white hairs on the forehead. Chelicera and fangs brown, labium dark brown. Sternum brown, shield-shaped, and with yellow dots. Abdomen dorsal view is brown; 2 pairs muscle points are at front, and ventral view is yellow. First leg is much thicker than other legs, and the color is darker and brown. Rows of 
A

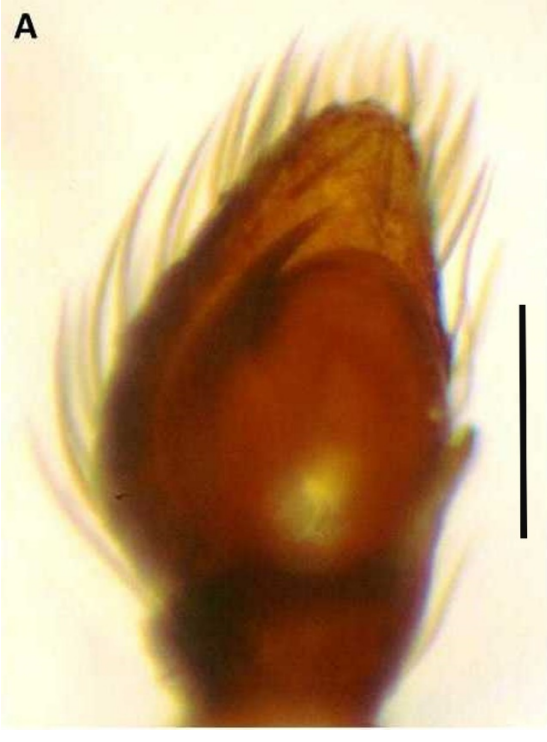

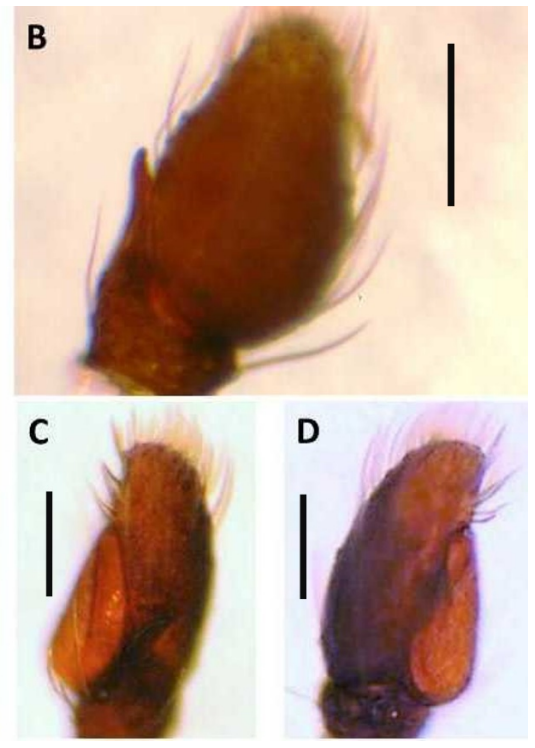

Figure 24. Microbianor formosana sp. nov. (A-B) Front pedipalp cymbium; (B) dorsal pedipalp cymbium; (C-D) lateral pedipalp cymbium and tibial apophysis. Scale bars: A-D $=0.2 \mathrm{~mm}$.

A

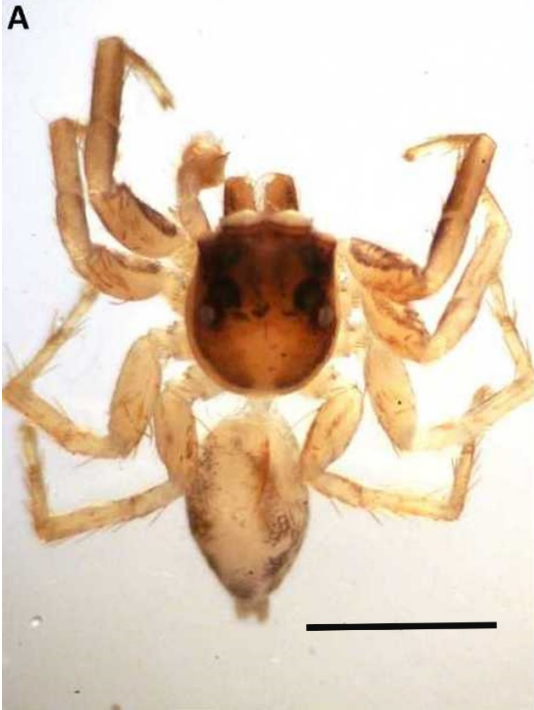

Figure 25. Male Plexippus petersi. (A) Dorsal view; (B) ventral view. Scale bars: A-B $=3$ $\mathrm{mm}$.

black shag are present on both sides of the femur, and the outer side black shag contains more than the inner side. After the midpoint of the patella approaching the tibia, thick, tassel-like, coarse, black hairs are observed. The second, third, and fourth legs are yellowish brown, with less hairs than on the first leg. Palpal organ dark brown, tibial apophysis single and spiked at the end, slightly curved outward toward the cymbium. Genitalia bulb oval, approximately one-fifth of its lower end is most prominent, and its lower edge does not cover the palpal organ tibia. Embolus short, straight, knife-shaped, and surround a quarter turn of the genitalia bulb. The position extends to the top. Cymbium contains more hairs, 
and the hairs are longer than those of the tibia. Although Microbianor formosana sp. nov. and M. furcatus (Haddad \& Wesolowska, 2013) are similar [24], differences exist in structures such as the first leg and the palpal organ, as shown in Table 2; thus, they are identified as different species.

\section{Ecology}

Casuarina forest of Aogu Wetland, Taiwan.

\section{Distribution}

Taiwan area.

\section{Plexippus petersi (Karsch, 1878) (new record) (Figures 25-28)}

Euophrys petersii Karsch, 1878a: 332, pl. 2, f. 7.

Plexippus petersi Simon, 1903a: 728; Zabka, 1985: 433, f. 464-470; Prószyński, 1987: 80; Próchniewicz, 1989: 219, f. 39-43; Zabka, 1990b: 172, f. 26-27; Song and Chai, 1991: 21, f. 12A-D; Xie, 1993: 359, f. 11-15; Peng et al., 1993: 183, f. 639-645; Barrion and Litsinger, 1995: 83, f. 41a-g; Song, Zhu, and Chen, 1999: 541, f. 310Q, 312C, 328M; Peng and Li, 2003b: 752, f. 3A-F; Jang, Choe, and Kim, 2007: 101, f. 3-4 (f); Yin et al., 2012: 1443, f. 787a-f.

Table 2. Comparison of first leg and palpal organ of male Microbianor formosana sp. nov. and $M$. furcatus.

\begin{tabular}{ccc}
\hline Species & First leg & Palpal organ \\
\hline M. formosana & $\begin{array}{c}\text { patella slender, length:width }=3: 1, \\
\text { tassel-like hair from the inner side } \\
\text { of the patella joint only after halfway. }\end{array}$ & $\begin{array}{c}\text { single tibial apophysis, embolus } \\
\text { straight, short, and knife-shaped. }\end{array}$ \\
M. furcatus & $\begin{array}{c}\text { patella stubby, length:width }=2: 1, \\
\text { tassel-like hair from the inner side } \\
\text { of the femur junction. }\end{array}$ & $\begin{array}{c}\text { tibial apophysis bifurcated, embolus } \\
\text { straight, short, and knife-shaped. }\end{array}$ \\
\hline
\end{tabular}
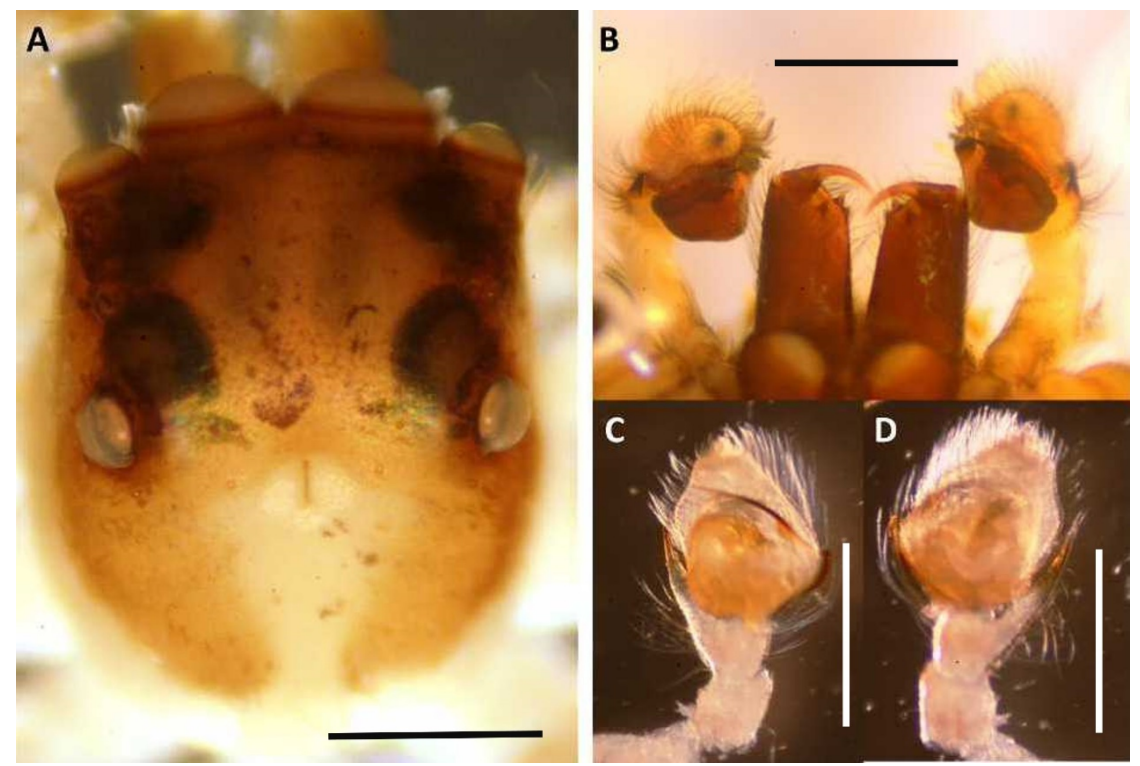

Figure 26. Male Plexippus petersi. (A) Cephalothorax dorsal view; (B) chelicera and pedipalp; (C-D) palpal organ. Scale bars: $A=3 \mathrm{~mm}, \mathrm{~B}-\mathrm{D}=1 \mathrm{~mm}$. 


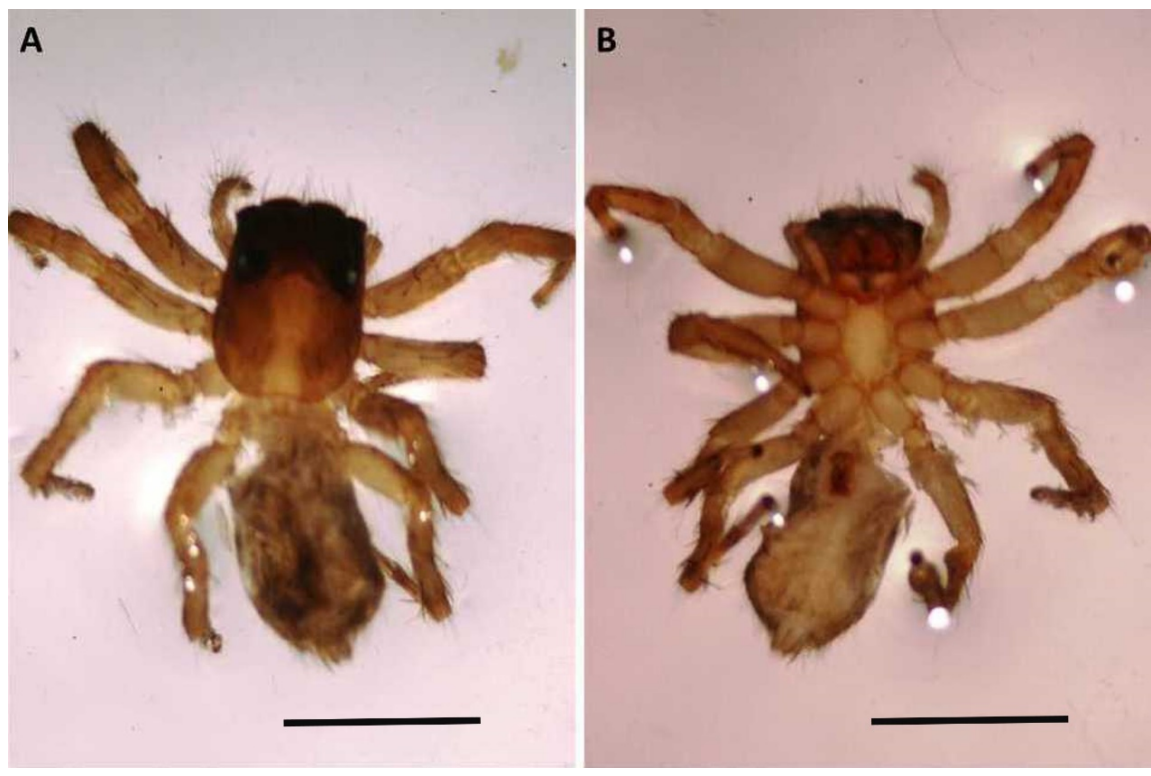

Figure 27. Female Plexippus petersi. (A) Dorsal view; (B) ventral view. Scale bars: A-B = $3 \mathrm{~mm}$.

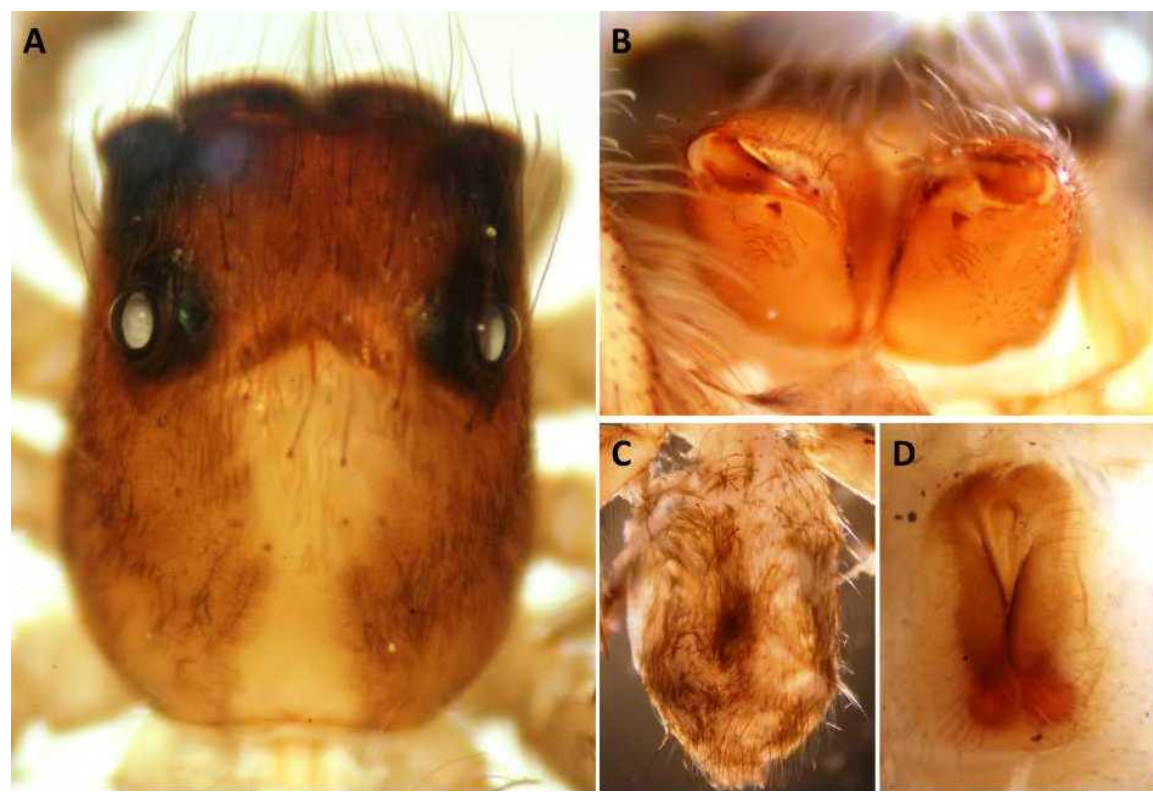

Figure 28. Female Plexippus petersi. (A) Cephalothorax dorsal view; (B) chelicera and retromarginal teeth; (C) abdomen ventral view; (D) epigynum. Scale bars: $A=1 \mathrm{~mm}$, (B) $\mathrm{D}=0.5 \mathrm{~mm}, \mathrm{C}=2 \mathrm{~mm}$.

\section{Type material}

Male total length $(\mathrm{mm})$ 5.45. Carapace length 2.65, width 2.20; abdomen length 2.80, width 1.96. MOA ratio, MOA-L:MOA-AW:MOA-PW = 1.02:1.17:1.22. AMI:AMLI: PMI:PMLI = 0.10:0.06:1.10:0.22. AME:ALE:PME:PLE $=0.60: 0.21: 0.08: 0.18$. Leg I $3.26(1.23,0.58,0.77,0.68)$; leg II $3.26(0.96,0.57$, $1.23,0.50)$; leg III $3.81(1.16,1.30,0.80,0.55)$; leg IV $3.31(1.05,1.35,0.45,0.46)$. Pedipalp $2.03(0.83,0.33,0.20,0.67)$. 
Female total length $(\mathrm{mm})$ 7.02. Carapace length 3.20, width 2.20; abdomen length 3.82, width 2.00. MOA ratio, MOA-L:MOA-AW:MOA-PW = 0.77:1.17:1.53. AMI:AMLI: PMI:PMLI = 0.10:0.07:1.33:0.21. AME:ALE:PME:PLE $=0.53: 0.20: 0.10: 0.27$. Leg I $4.53(1.50,1.83,0.67,0.53)$; leg II $3.37(1.50,1.67$, $0.67,053)$; leg III $4.84(1.67,1.67,0.67,0.83)$; leg IV $5.73(1.83,1.83,1.00,1.07)$.

\section{Characteristics}

\section{Male}

Cephalothorax brown, ocular area black-brown, covered with black hairs, from the PLE to the carapace with a wide black longitudinal band on the left and right sides. AER recurve. Chelicera and fangs are brown. Two promarginal teeth, 1 retromarginal tooth. Labium brown. Sternum yellow, with a light U-shaped at the front end, and the rear end does not extend to the fourth leg coxa. Abdomen long ovoid, yellow, with several black, long hairs in the center, and 2 dark brown longitudinal bands on the 2 sides, separated by a yellow horizontal strip at two-thirds the abdomen. Several brown mountain-shaped patterns can be seen at the end of the center of the dorsal of abdomen. Abdomen ventral is yellowish brown, with a large dark brown wedge-shaped spot under the epigastric furrow. Spinnerets are grayish yellow. The legs yellow, hairy, with dark brown longitudinal spots on both sides. Genitalia bulb noncircular and with a protuberance underneath. Sperm duct visible, extending upward along the side of the genitalia bulb. Embolus has a slender tip. The front edge of the genitalia bulb is higher than the base of the embolus. Tibia has thick clusters of white hairs and tibial apophysis monoliths. Close to the cymbium, the end of the tibial apophysis exceeds the base of the embolus, and the dorsal side of the cymbium is covered with numerous white hairs. The palpal organ structure of this species is similar to that of $P$. paykulli (Audouin, 1826). In this species, the embolus is relatively slender, and the front edge of the tip of the tibial apophysis exceeds the embolus.

\section{Female}

Cephalothorax brown, with black hairs, black around the eyes, ocular area less than half the length of the cephalothorax. Ocular area has a yellow longi-tudinal band behind the center. AER recurve. Chelicera and fangs are are brown and fangs are reddish brown. Two promarginal teeth, 1 retromarginal tooth. Labium yellow, width is greater than length. Sternum light yellow, with white burrs on the rear end. Abdomen oval, dorsal view blackish brown with a thick grayish white longitudinal band in the center. This central longitudinal band protrudes to the left and right at the center and two-thirds of the abdo-men, forming 2 pairs of small white spots. Several thin, arc-shaped, horizontal bands at the end of the central longitudinal band. Abdomen ventral view yel-low. Many black spots are evenly distributed under the epigastric furrow. Spots directly above the spinnerets are largest and are grayish yellow. Pedi-palp yellow and black, with hairs. Leg brown with white hairs, and with many dark spots in the dorsal view. Black bristles on the dorsal side of the femur, 3 pairs of spines in the tibia ventral view, 2 pairs of spines in the metatarsus ventral view. Epigynum long, its center 
having a gutter-shaped ditch. Front positioned hood. The copulatory openings on both sides are longitudinal, long, and crack-like. Spermatheca round, and 2 are visible. The main difference of this species from P. paykulli lies is in the position of the hood; specifically, it has a front position in this species and a middle position in P. paykulli.

The top front edge of the tibial apophysis of the male Plexippus petersi exceeds the base of the embolus (Figure 25). The position of the epigynum of the female is higher than that of $P$. paykulli (Figure 28). The 2 species can be distinguished.

\section{Ecology}

Terrestrial shrubs of Aogu Wetland, Taiwan.

\section{Distribution}

Chinese Mainland, Japan, Vietnam, Malay Islands, New Guinea, Taiwan area.

\section{Pseudicius sp. (Figure 29) \\ Characteristics \\ Female}

Cephalothorax flat, dark brown, ocular area black, the edges of the cephalothorax and the ocular area covered with white hairs. The ocular area is less than half the length of the cephalothorax. PME located in the middle of ALE and PLE; under the PME and PLE is a row of stridulatory spines [21]. AER recurve. Chelicera and fangs are reddish brown. Two promarginal teeth, 1 retromarginal tooth. Labium reddish brown. Sternum width is greater than length, brown and with white hairs on the edges. Abdomen oval, dorsal view black and yellow, and the black part is covered with numerous black hairs. A short white longitudinal band is in the

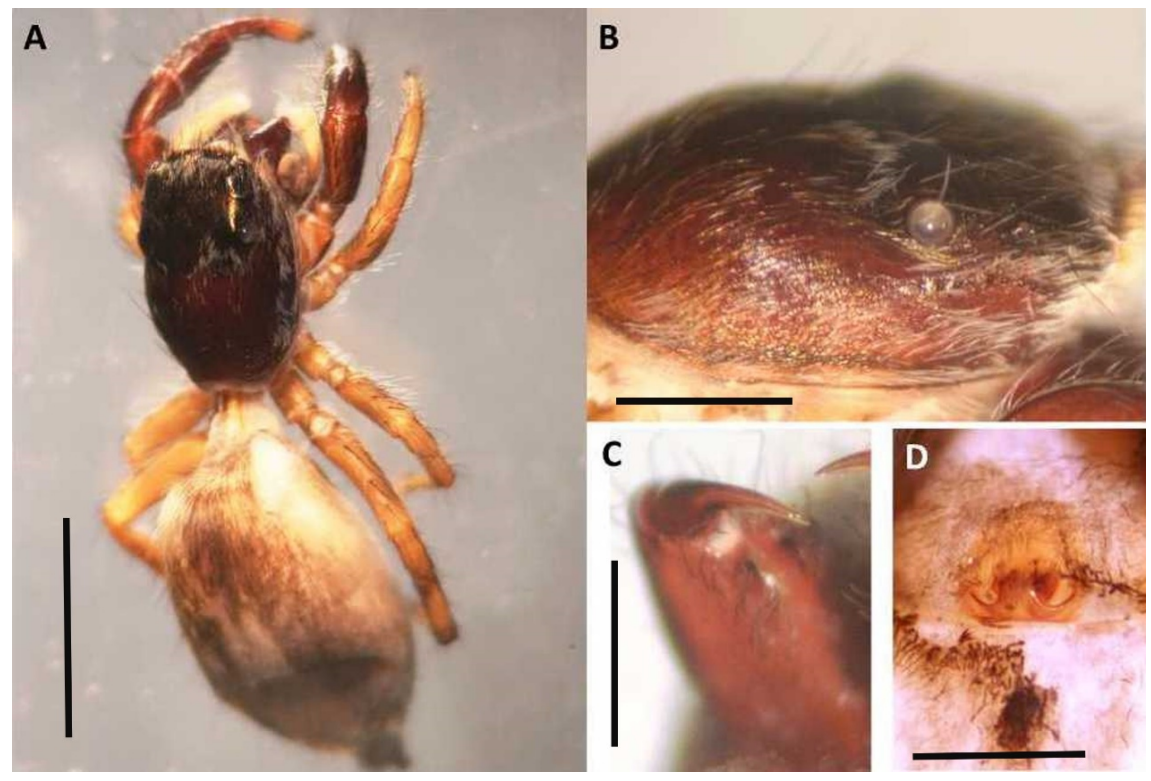

Figure 29. Female Pseudicius sp. (A) Dorsal view; (B) cephalothorax and microspines (stridulatory spines); (C) chelicerae; (D) epigynum. Scale bars: $A=3 \mathrm{~mm}, \mathrm{~B}=1 \mathrm{~mm}, \mathrm{C}=$ $2 \mathrm{~mm}, \mathrm{D}=0.2 \mathrm{~mm}$. 
center. The end of the longitudinal band is faint with 2 horizontal rings. Ventral view is yellow. Rows of horizontal short black hairs are present along the epigastric furrow. Two vertical gray bands are present under the epigastric furrow. Spinnerets are grayish yellow. Pedipalp yellow, with many long white hairs on the knee joints, the outer side of the tibia, and the entire tarsus. The first leg is the thickest, and its femur is thickest and reddish brown with sporadic long black hairs on the outside of each section. The second, third, and fourth legs are lighter in color and yellowish brown. The epigynum is keratinized.

\section{Rhene rubrigera (Thorell, 1887) (new record) (Figure 30, Figure 31)}

Homalattus rubriger Thorell, 1887: 347.

Homalattus phoeniceus Simon, 1888b: 203.

Rhene phoenicea Simon, 1901a: 635, 638, f. 750.

Rhene rubrigera Simon, 1903g: 733; Prószyński, 1984a: 121; Zabka, 1985: 444, f. 544-562; Peng et al., 1993: 203, f. 715-722; Song, Zhu, and Chen, 1999: 538, f. 314O-P, 315C-D, 329F; Yin et al., 2012: 1463, f. 797a-h; Sen et al., 2015: 30, f. 67-71, pl. 12.

\section{Type Material}

Male total length $(\mathrm{mm})$ 5.55. Carapace length 2.50, width 2.45; abdomen length 3.05, width 2.10. MOA ratio, MOA-L:MOA-AW:MOA-PW = 0.90:0.96:1.63. AMI:AMLI: PMI:PMLI $=0.03: 0.10: 1.50: 0.86$ AME:ALE:PME:PLE = 0.47:024:0.06:0.10. Leg I $5.13(1.80,2.10,0.72,0.51)$; leg II $3.45(1.25,1.20,0.55$, $0.45)$; leg III $2.65(0.60,0.95,0.50,0.60)$; leg IV $2.80(1.00,1.00,0.40,0.40)$. Pedipalp $2.10(0.80,0.25,0.25,0.80)$.
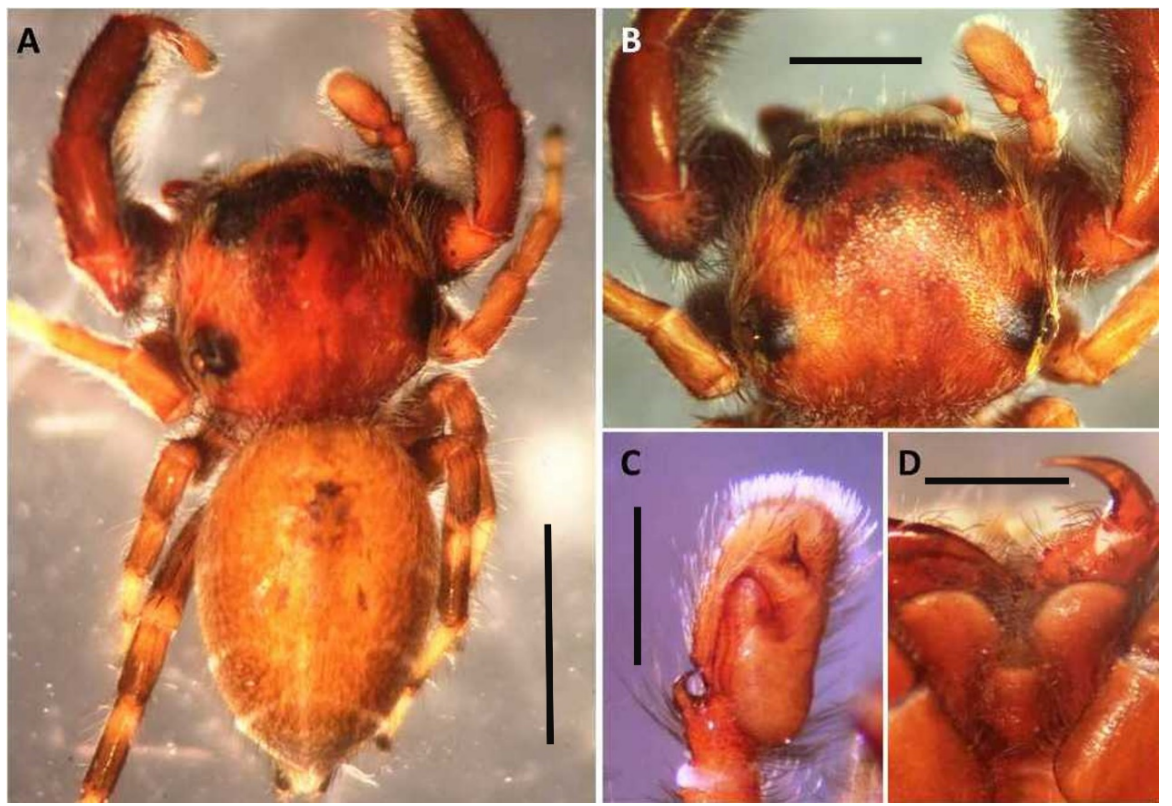

Figure 30. Male Rhene rubrigera. (A) Dorsal view; (B) cephalothorax; (C) palpal organ; (D) promarginal and retromarginal teeth. Scale bars: $A=2 \mathrm{~mm}, \mathrm{~B}, \mathrm{D}=1 \mathrm{~mm}, \mathrm{C}=0.5$ $\mathrm{mm}$. 

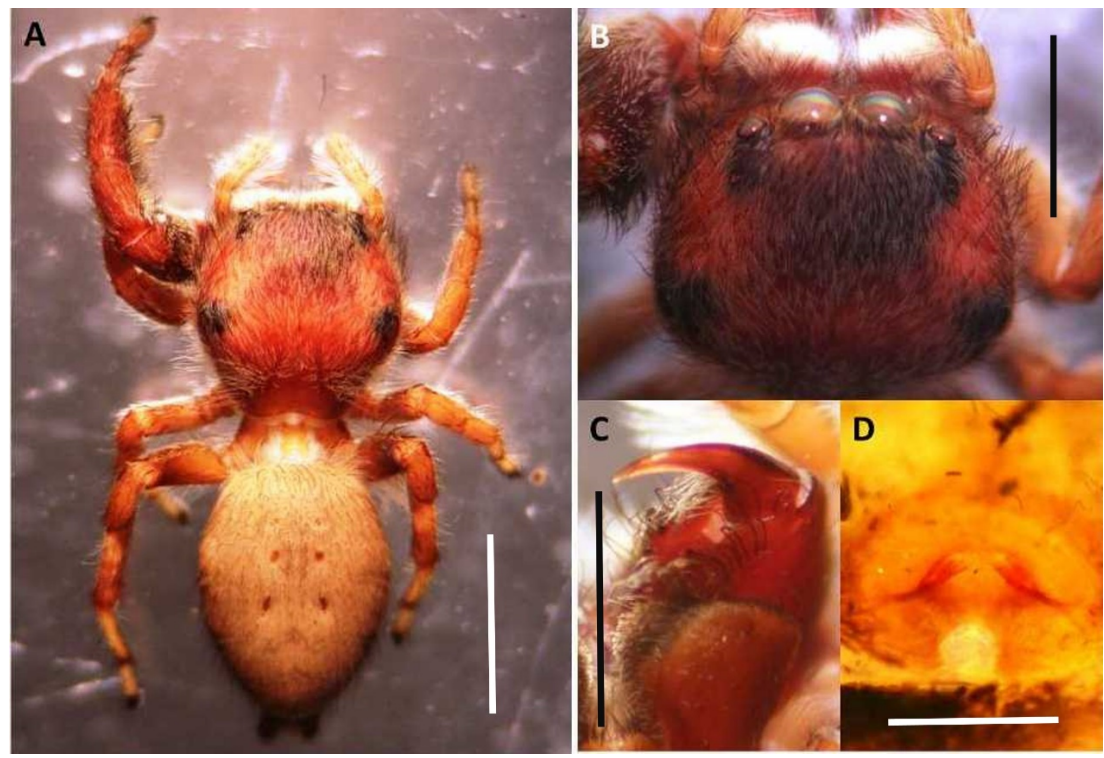

Figure 31. Female Rhene rubrigera. (A) Dorsal view; (B) cephalothorax; (C) promarginal and retromarginal teeth; (D) epigynum. Scale bars: $A=2 \mathrm{~mm}, \mathrm{~B}=1 \mathrm{~mm}, \mathrm{C}=0.5 \mathrm{~mm}, \mathrm{D}$ $=0.2 \mathrm{~mm}$.

Female total length 5.85. Carapace length 2.20, width 2.20; abdomen length 3.65, width 2.30. MOA ratio, MOA-L:MOA-AW:MOA-PW $=0.73: 0.82: 1.43$. AMI:AMLI:PMI:PMLI = 0.12:0.10:1.30:0.83. AME:ALE:PME:PLE = 0.37:0.27:0.07:0.17. Leg I 3.98 (1.25, 1.68, 0.50, 0.55); leg II $3.25(1.00,1.20,0.45$, $0.60)$; leg III $2.70(0.80,0.95,0.40,0.55)$; leg IV $2.60(0.85,1.05,0.30,0.40)$.

\section{Characteristics \\ Male}

Cephalothorax flat, dark brown, and ocular area black. Ocular area and its edges are covered with white hairs. The ocular area is less than half the length of the cephalothorax. PME located midpoint between the anterior and posterior eyes. AER recurve. Chelicera and fangs are reddish brown. Two promarginal teeth, 1 retromarginal tooth. Labium brown. Sternum yellowish brown, darker center. Abdomen long oval, dorsal view yellowish brown, edge dark brown with white hairs, 3 pairs of muscle marks. The abdomen dorsal has 3 pairs of horizontal yellow pinstripes extending from the center to the sides of the abdomen. Yellow ventral surface of the abdomen, with a large black area in the center and its width is approximately half the width of the abdomen, and the book lung is dark brown. Spinnerets are dark brown. First leg longest, thickest, dark brown. Femur, patella, and tibia with thick burrs on the inside. Second, third, and fourth legs brown. Genitalia bulb length is greater than width, kidney-shaped. Sperm duct visible, embolus upright and short needle-shaped, carried above the genitalia bulb, tibial apophysis mono-protruding, single helix-shaped, curved toward the cymbium, cymbium longer than tibia, hairy. The main difference between this species and $R$. atrata (Karsch, 1881) is the shape of the embolus. In this species, the embolus is upright and short needle-shaped, and that of $R$. rubrigera has a broad base and a curved tip. 


\section{Female}

The appearance characteristics are identical to those of the male. Abdomen ventral view yellow, and the large black patch in the middle is lighter, with yellow spots scattered within it. The abdomen dorsal has 3 pairs of horizontal lightly yellow pinstripes, which was less obvious than that of male spider. Spinnerets are yellowish brown, genital groove black, epigynum light red. The mating hole is horizontal. The embolus of $R$. rubrigera is upright and short needle-shaped (Figure 30(C)), and it can be clearly distinguished from the embolus of $R$. atrata, with a broad base and a curved tip.

\section{Ecology}

Waterside shrubs of Aogu Wetland, Taiwan.

\section{Distribution}

Chinese Mainland, India to Sumatra, Mexico, Hawaii, Taiwan area.

\section{Synagelides zhilcova Prószyński, 1979 (new record) (Figure 32)}

Synagelides zhilcovae Prószyński, 1979: 319, f. 316-317; Dunin, 1984b: 139, f. 65 (f); Peng et al., 1993: 229, f. 816-818 (f); Song, Zhu, and Chen, 1999: 561, f. 320H, 321A, 329R (f); Kim and Kim, 2000a: 186, f. 2A-E (f); Ono, Ikeda, and Kono, 2009: 588, f. 345-346 (f); Kim and Lee, 2014: 141, f. 100A-B, pl. 29 (f).

\section{Type Material}

Female total length $(\mathrm{mm})$ 4.00. Carapace length 1.50, width 1.00; abdomen length 2.50, width 1.05. MOA ratio, MOA-L:MOA-AW:MOA-PW = 0.37:0.67:0.93. AMI:AMLI:PMI:PMLI $=0.03: 0.03: 0.83: 0.40$. AME:ALE:PME:PLE $=0.30: 0.13: 0.05: 0.13$. Leg I $1.75(0.60,0.65,0.30,0.20)$; leg II $1.40(0.45,0.50$, $0.30,0.15)$; leg III 1.35 (0.45, 0.45, 0.30, 0.15); leg IV $1.85(0.60,0.75,0.30,0.20)$.
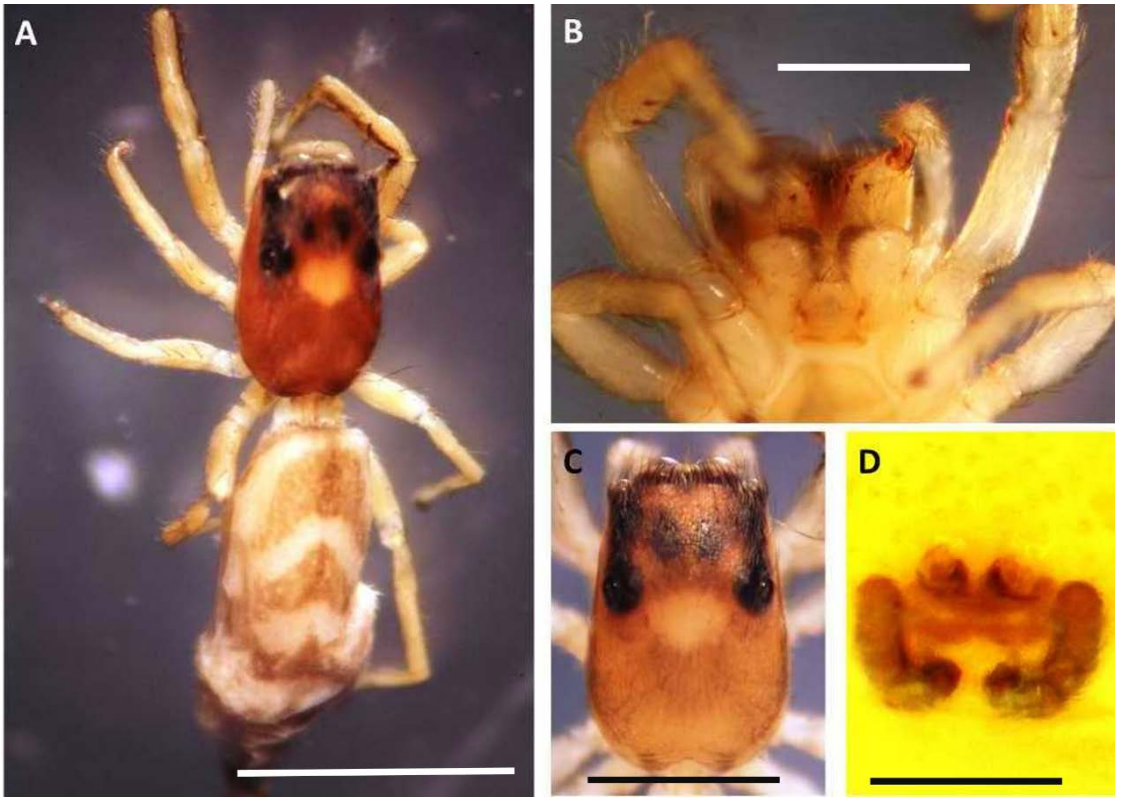

Figure 32. Female Synagelides zhilcovae. (A) Dorsal view; (B) chelicera; promarginal and retromarginal teeth; (C) cephalothorax; (D) epigynum. Scale bars: $\mathrm{A}=2 \mathrm{~mm}, \mathrm{~B}, \mathrm{C}=1$ $\mathrm{mm}, \mathrm{C}=0.2 \mathrm{~mm}$. 


\section{Characteristics}

\section{Female}

Body slender and long. Cephalothorax brown, front narrow and back wide. From ALE to PLE a black longitudinal band is formed, covered with black hairs. PLE is black around, ocular area has 2 large black elliptical spots, and thoracic groove witha yellow spot block; the lower radial groove is obvious. AER recurve. Chelicera yellow, fangs brown. Two promarginal teeth, 1 retro-marginal tooth. Labium light yellow. Sternum light yellow, shield-shaped, front truncated, rear pointed tail.

Abdomen spindle-shaped, dorsal view brown, with 1 pair of light-yellow stripes on the front edge and 2 pairs of light-yellow, oblique spots on the back, forming 2 "handstand Vs," with 2 - 3 thick, light-yellow horizontal stripes at the end. Ventral view is yellow. Spinnerets are light yellow. Leg lengths are in the order of IV > I > II > III. Legs yellow. The first leg has a black longitudinal band from the inner side of the femur. The tibia has 2 pairs of acupuncture-like needles on the ventral side. Epigynum is red, with a pair of mating tubes clearly visible.

\section{Ecology}

Waterside shrubs of Aogu Wetland, Taiwan.

\section{Distribution}

Russia, Chinese Mainland, Japan, South Korea, Taiwan area.

\section{Discussion}

The Euophrys taiwanus sp. nov. described in this study belongs to the subfamily Euophryinae. This subfamily includes Euophrys, Pseudeuophrys, Talavera, Neon, and 4 other genera of spiders in China and neighboring countries. Their common morphological characteristics are small size, with a body length of less than $4 \mathrm{~mm}$, and an appearance dissimilar to ants [21].

The embolus of Euophrys is smaller than that of Pseudeuophrys and larger than that of Talavera. The embolus of Euophrys is wrapped around the top of the genital bulb. The embolus of Pseudeuophrys is looped around the recess or recess at the top of the genitalia bulb. The embolus of Talavera is needle-like or thorn-like, and that of Euophrys bends.

For the subfamily Pelleninae within the family Salticidae, 3 genera have been recorded (Bianor, Harmochirus, Sibanor), with 4 species recorded in Taiwan [8]. This subfamily is characterized by its diamond-shaped cephalothorax, which is used in this study to report a newly recorded genus Microbianor.

The PME of Bianor is closer to the ALE, whereas in the 3 other genera, it is at the midpoint between the ALE and the PLE. Only the side of the genitalia bulb of Sibanor has papillary protrusions, and the 3 other genera (Bianor, Harmochirus, Microbianor) do not papillary protrusion [25].

\section{Acknowledgements}

We are grateful to Mr. Keng-Yau Chang, Mr. Po-Jaing Shie, Mr. Shir-Zu Lin, 
Mr. Meng-Han Shie, Mr. Wu-Chanl Chang, Mr. Yu-An Lin, Mr. Ya-Su Luo, Mr. Han-Chang Chen, and Mrs. Jun-Fang Chang for their help with fieldwork and data collection. This study was supported by Chiayi County Government and by the Construction and Planning Agency of the Ministry of the Interior.

\section{Conflicts of Interest}

The authors have no conflicts of interest to declare.

\section{References}

[1] Matsumura, S. (1910) Die schädlichen und nützlichen insekten: Vom zuckerrohr Formosas. The Keiseisha, Tokyo. 288 p. https://doi.org/10.5962/bhl.title.35666

[2] Lee, C.-L. (1964) The Spiders of Taiwan. Da-Jian Bank Quarterly, 15, 254-290.

[3] Zhum, Y.-I. and Okuma, C. (1974) A Checklist of Spiders in Taiwan. Annual of Taiwan Museum, 17, 29-49.

[4] Zhum, Y.-I. and Okuma, C. (1975) A Checklist of Spiders in Taiwan, Continued. Annual of Taiwan Museum, 18, 101-119.

[5] Chen, S.-H. (1996) A Checklist of Spiders in Taiwan. Annual of Taiwan Museum, 39, 123-155.

[6] Bao, Y.H. and Peng, X.J. (2002) Six New Species of Jumping Spiders (Araneae: Salticidae) from Hui-Sun Experimental Forest Station, Taiwan. Zoological Studies, 41, 403-411. http://zoolstud.sinica.edu.tw/Journals/41.4/403.pdf

[7] Huang, J.-W. (2004) Taxonomic Study of Myrmarachne (Araneae: Salticidae) from Taiwan. Master's Thesis, Department of Life Sciences, Sun Yat-sen University, Kaohsiung, 87 p.

[8] Chen, S.-H. and Chen, C.-C. (2013) A Taxonomic Study on the Spiders of Plexippoida (Araneae: Salticidae) of Taiwan. Master's Thesis, Department of Life Science, Taiwan Normal University, Taipei, 205 p. http://rportal.lib.ntnu.edu.tw:80/handle/20.500.12235/104392

[9] Yamasaki, T. (2013) A New Species of the Genus Myrmarachne (Araneae: Salticidae) from Tamsui, Taiwan. Acta Arachnologica, 62, 29-31. https://doi.org/10.2476/asjaa.62.29

[10] Lin, T.-Y. (2015) A Study on the Spider Cluster of Aogu Wetland, Chiayi County. Master's Thesis, Department of Environmental Engineering, Kun-Shan University, Tainan, $97 \mathrm{p}$.

[11] Lin, Y.-C., Chen, K.-N., Chen, K.-X. and Ueng, Y.-T. (2019) Population Fluctuation and Life History Traits of Tiny Leafhopper Singapora nigropunctata Mahmood, 1967 (Hemiptera: Cicadellidae) in Southwestern Taiwan. Agricultural Science Research Journal, 9, 151-159.

[12] Yang, J.Y.-C. and Ueng, Y.-T. (2011) Taiwan's Wetlands of Importance. Urban and Rural Development Branch, Construction and Planning Agency, Ministry of the Interior, Taipei, $192 \mathrm{p}$.

[13] Davies, V.T. and Zabka, M. (1989) Illustrated Keys to the Genera of Jumping Spiders (Araneae: Salticidae) in Australia. Memoirs of the Queensland Museum, 27, 189-266.

[14] Simon, E. (1903) Histoire naturelle des araignées. Paris, 2, 669-1080. https://www.biodiversitylibrary.org/item/119058\#page/6/mode/1up 
[15] Ono, H., Ikeda, H. and Kono, R. (2009) Salticidae. In: Ono, H., Ed., The Spiders of Japan with Keys to the Families and Genera and Illustrations of the Species, Tokai University Press, Kanagawa, 558-588.

[16] Kim, B.W. and Kim, J.P. (2000) A Revision of the Genus Synagelides Strand, 1906 (Araneae, Salticidae) in Korea. Korean Journal of Systematic Zoology, 16, 183-190.

[17] Kim, B.W., Kim, J.P. and Cho, J.H. (2003) A Revision of the Genera Euophrys, Pseudeuophrys, and Talavera (Araneae: Salticiadae) from Korea. Korean Arachnology, 19, 89-102.

[18] Kim, S.T. and Lee, S.Y. (2014) Arthropoda: Arachnida: Araneae: Clubionidae, Corinnidae, Salticidae, Segestriidae. Spiders. Invertebrate Fauna of Korea, 21, 1-186.

[19] Zabka, M. (1985) Systematic and Zoogeographic Study on the Family Salticidae (Araneae) from Viet-Nam. Annales Zoologici, Warszawa, 39, 197-485.

[20] Zabka, M. and Waldock, J. (2012) Salticidae (Arachnida: Araneae) from Oriental, Australian and Pacific Regions. Genus Cosmophasis Simon, 1901. Annales Zoologici, 62, 115-198. https://doi.org/10.3161/000345412X633694

[21] Prószynski, J. (2008) Key to Identification of Genera of Salticidae (Araneae) Known from China and Adjacent Countries.

[22] World Spider Catalog (2021) World Spider Catalog Version 22.0. Natural History Museum Bern. https://wsc.nmbe.ch/

[23] Jumping-Spiders Company (2021) Jumping Spiders (Arachnida: Araneae: Salticidae) of the World. http://www.jumping-spiders.com/

[24] Haddad, C.R. and Wesołowska, W. (2013) Additions to the Jumping Spider Fauna of South Africa (Araneae: Salticidae). Genus, 24, 459-501.

[25] Logunov, D.V. (2001) A Redefinition of the Genera Bianor Peckham \& Peckham, 1885 and Harmochirus Simon, 1885, with the Establishment of a New Genus Sibianor Gen. n. (Aranei: Salticidae). Arthropoda Selecta, 9, 221-286. 


\section{Appendix 1}

All species of Salticidae spiders were collected from Aogu Wetland in Chiayi County, Taiwan (from August 2013 to August 2014, N = 32).

\begin{tabular}{|c|c|c|c|c|}
\hline Species & Specimen number & Collection date and quantity & State & Note \\
\hline Bianor angulosus & NMNS-8370-005 & $2014 / 6 / 7=1$ 우, $7 / 10=2$,, $9 / 7=1 \widehat{ }$ & & Figure 2 \\
\hline Carrhotus tristi & NMNS-8370-006 & $2013 / 12 / 1=1 \hat{\partial}, 2014 / 5 / 3=1{ }^{\lambda}$ & New record & Figure 8, Figure 9 \\
\hline Euophrys taiwanus & NMNS-8370-001 & $2014 / 2 / 3=1 \hat{\partial}$, Holotype & New Species & Figure 10, Figure 11 \\
\hline Euophrys taiwanus & NMNS-8370-002 & $2014 / 2 / 3=2 q$, Paratypes & New Species & Figure 12, Figure 13 \\
\hline Evarcha bulbosa & NMNS-8370-007 & $2013 / 9 / 7=2$ ㅇ, $2014 / 5 / 3=1{ }^{\lambda}$ & New record & Figure 14, Figure 15 \\
\hline Evarcha flavocincta & NMNS-8370-008 & $2013 / 9 / 7=1 ㅇ, 12 / 2=1$ ㅇ & & Figure 7 \\
\hline Evarcha chiayiensis & NMNS-8370-003 & 2014/4/4 = 1ð, Holotype & New Species & Figure 16, Figure 17 \\
\hline Menemerus bivittatus & NMNS-8370-009 & $2013 / 9 / 7=1 \partial^{\lambda} \& 1$ 우 & New record & Figures 22-26 \\
\hline Microbianor formosana & NMNS-8370-004 & $2014 / 8 / 2=1 \delta$, Holotype & New Species & Figures 22-24 \\
\hline Myrmarachne formosicola & NMNS-8370-010 & $2014 / 8 / 2=1 \precsim \& 1$ 우 & & Figure 10 \\
\hline Phintella versicolor & NMNS-8370-015 & $2014 / 7 / 10=1 \sigma^{\pi}$ & & Figure 6 \\
\hline Plexippus petersi & NMNS-8370-011 & $2014 / 3 / 8=1 \delta^{\lambda} \& 1$ ㅇ & New record & Figures 25-28 \\
\hline Rhene rubrigera & NMNS-8370-012 & $2014 / 1 / 4=2$,, $2 / 3=1+, 3 / 8=1{ }^{\lambda}$ & New record & Figure 30, Figure 31 \\
\hline Sibianor pullus & NMNS-8370-013 & $2014 / 5 / 3=1$ 우 & & Figure 3 \\
\hline Synagelides zhilcovae & NMNS-8370-014 & $2014 / 6 / 23=2+, 7 / 10=1$ 우 & New record & Figure 32 \\
\hline Pseudicius $\mathrm{sp}$ & Missing specimen & 1 우 & & Figure 29 \\
\hline
\end{tabular}

